\title{
Advances in epidermal growth factor receptor specific immunotherapy: lessons to be learned from armed antibodies
}

\author{
Fleury Augustin Nsole Biteghe ${ }^{1, *}$, Neelakshi Mungra ${ }^{2, *}$, Nyangone Ekome Toung \\ Chalomie ${ }^{4}$, Jean De La Croix Ndong ${ }^{5}$, Jean Engohang-Ndong ${ }^{6}$, Guillaume Vignaux ${ }^{7}$, \\ Eden Padayachee ${ }^{8}$, Krupa Naran ${ }^{2, *}$ and Stefan Barth ${ }^{2,3, *}$ \\ ${ }^{1}$ Department of Radiation Oncology and Biomedical Sciences, Cedars-Sinai Medical, Los Angeles, CA, USA \\ ${ }^{2}$ Medical Biotechnology \& Immunotherapy Research Unit, Institute of Infectious Disease and Molecular Medicine, Faculty of \\ Health Sciences, University of Cape Town, Cape Town, South Africa \\ ${ }^{3}$ South African Research Chair in Cancer Biotechnology, Department of Integrative Biomedical Sciences, Faculty of Health \\ Sciences, University of Cape Town, Cape Town, South Africa \\ ${ }^{4}$ Sun Yat-Sen University, Zhongshan Medical School, Guangzhou, China \\ ${ }^{5}$ Department of Orthopedic Surgery, New York University School of Medicine, New York, NY, USA \\ ${ }^{6}$ Department of Biological Sciences, Kent State University at Tuscarawas, New Philadelphia, OH, USA \\ ${ }^{7}$ Arctic Slope Regional Corporation Federal, Beltsville, MD, USA \\ ${ }^{8}$ Department of Physiology, University of Kentucky, Lexington, KY, USA \\ *These authors contributed equally to this work \\ Correspondence to: Stefan Barth, email: stefan.barth@uct.ac.za
}

Keywords: epidermal growth factor receptor (EGFR); recombinant immunotoxins (ITs); targeted human cytolytic fusion proteins (hCFPs); recombinant antibody-drug conjugates (rADCs); recombinant antibody photoimmunoconjugates (rAPCs) Received: May 30, 2020 Accepted: August 11, 2020 Published: September 22, 2020

Copyright: $\odot 2020$ Biteghe et al. This is an open access article distributed under the terms of the Creative Commons Attribution License (CC BY 3.0), which permits unrestricted use, distribution, and reproduction in any medium, provided the original author and source are credited.

\section{ABSTRACT}

The epidermal growth factor receptor (EGFR) has been recognized as an important therapeutic target in oncology. It is commonly overexpressed in a variety of solid tumors and is critically involved in cell survival, proliferation, metastasis, and angiogenesis. This multi-dimensional role of EGFR in the progression and aggressiveness of cancer, has evolved from conventional to more targeted therapeutic approaches. With the advent of hybridoma technology and phage display techniques, the first anti-EGFR monoclonal antibodies (mAbs) (Cetuximab and Panitumumab) were developed. Due to major limitations including host immune reactions and poor tumor penetration, these antibodies were modified and used as guiding mechanisms for the specific delivery of readily available chemotherapeutic agents or plants/bacterial toxins, giving rise to antibody-drug conjugates (ADCs) and immunotoxins (ITs), respectively. Continued refinement of ITs led to deimmunization strategies based on depletion of B and T-cell epitopes or substitution of non-human toxins leading to a growing repertoire of human enzymes capable of inducing cell death. Similarly, the modification of classical ADCs has resulted in the first, fully recombinant versions. In this review, we discuss significant advancements in EGFR-targeting immunoconjugates, including ITs and recombinant photoactivable ADCs, which serve as a blueprint for further developments in the evolving domain of cancer immunotherapy.

\section{INTRODUCTION}

Epidermal growth factor receptor (EGFR) belongs to a family of transmembrane proteins that are known as tyrosine kinases (ErbB family) and made of four members known as: EGFR/HER1, ErbB2/HER2, ErbB3/HER3, and ErbB4/HER4 [1-4]. EGFR is a $170 \mathrm{kDa}$ glycoprotein, known as HER1 or c-ErbB-1, and was the first member of receptor tyrosine kinase (RTK) to be described [4]. EGFR is characterized by an extracellular ligand 
binding domain (ectodomain), a single transmembrane domain (TM), and an intracellular domain with tyrosine function [1-3]. EGFR activation begins with ligand binding induced ectodomain dimerization (homo- and/or heterodimerization), causing the autotransphosphorylation of tyrosine residues located on the intracellular tyrosine kinase domain [3, 4]. This tyrosinase phosphorylation consequently recruits signal transducers and activators of intracellular substrates such as Rat sarcoma (Ras). Once activated, Ras activates downstream signaling cascades such as RAF/MEK1/2/ERK1/2, and/or PI3k/ Akt, regulating cell proliferation, survival, differentiation, and migration $[1,2,5]$. The EGFR signaling pathway is tightly regulated under normal conditions. However, EGFR has been aberrantly expressed in many cancers due to mutations associated with poor cancer prognosis [4, 6-12]. Hence, developing new therapeutic approaches that target EGFR, becomes very pertinent.

So far, two EGFR-targeted therapeutic approaches have been developed using antagonist monoclonal antibodies (mAbs) or small molecule tyrosine kinase inhibitors (TKIs), either blocking ligand binding or inhibiting tyrosinase function by preventing adenosine triphosphate (ATP) binding to the EGFR intracellular domain [13]. Both therapeutic strategies have been clinically approved for treating multiple cancers [12-14]. However, compromised efficacy of TKIs is associated with increased mutations in tyrosine kinase intracellular domains. These mutations were found to drive resistance to TKIs by increasing ATP avidity to the targeted domain or by constitutively activating downstream signaling pathways causing treatment failure [15-18]. Conversely to TKIs, mAbs partly exert their cytotoxic effects by reducing EGFR ectodomain density through induction of receptor mediated endocytosis or by activating antibodydependent cellular cytotoxicity (ADCC) towards EGFR positive cancer cells [19-21]. To date, five mAbs have been clinically approved and target different ErbB family members: EGFR (HER1): cetuximab (2004, head and neck and colorectal cancers), panitumumab (2006, colorectal cancer), necitumumab (2015, non-small lung cancer); and HER2: trastuzumab (1998, breast cancer) and pertuzumab (2012, breast cancer) [14, 19-26]. Although promising, these naked antibody-based monotherapies have achieved poorer clinical responses, than when combined with conventional chemotherapy, radiotherapy or TKIs [23]. Despite obvious clinical benefits, these combination therapies were associated with undesirable side effects, partly owing to mAbs bulky size limiting tumor penetration or rodent origin, inducing an immune response when used in immunocompetent patients [27, 28]. Consequently, mAbs were considered to be armed with cytotoxic drugs to generate so called antibody-drug conjugates (ADCs) which could tilt the toxicity/therapeutic balance towards a more beneficial specific therapeutic efficacy. These ADCs are able to achieve improved selective cytotoxicity based on their ability to discriminate and exploit the differential cell surface expression of tumor associated antigens (TAA) between diseased and healthy tissues, and use it as a mechanism to specifically deliver the conjugated cytotoxic payloads to the tumor site [2931]. Major drawbacks of antibodies chemically conjugated to highly potent cytotoxic small molecule toxins are still related to immunogenicity but also toxin release causing off-target toxicities. Therefore, further ADC refinement should ideally produce immunoconjugates, which are nonimmunogenic and non-toxic in their native administered state, with toxicity only unleashed when internalized into targeted tumor cells. Protein engineering was consequently allowing to replace small molecule toxins by cytotoxic proteins originally derived from plants and bacteria in so-called immunotoxins (ITs) and later by replacing these highly immunogenic protein toxins by human apoptosis inducing enzymes to generate targeted human cytolytic fusion proteins (hCFPs) for cancer therapy [32-34]. In spite of their initial preclinical promises, enzymes to be used for the generation of hCFPs might be blocked by the activity of their natural inhibitors upregulated in tumor cells to allow escape from immune responses [32, $34,35]$. To date, preclinical proofs of concept have been described for hCFPs with improved rationally designed inhibitor insensitive variants of the protease granzyme $\mathrm{B}$ and the RNase angiogenin in addition to other human cytoskeleton interfering proteins, such as the microtubuleassociated protein tau, or death-associated protein kinases to treat various cancers [32, 33, 35-37]. Likewise, in order to reduce off target effects described for released small molecule toxins from ADCs, light sensitive antibodyphotoconjugates (APCs) were developed by replacing the toxic compounds by light inducible photosensitizers (PSs) showing essentially no toxicity to normal/non-irradiated tissues, as they require an extra step of light activation to exert their phototoxicity $[9,11,38-43]$.

Altogether, these recent biotechnological advances have expanded the repertoire of armed antibodies through the development of different forms of ADCs. Hence, this review aims to introduce selected antibodybased therapeutic approaches and corresponding key technologies, allowing to describe recent developments exemplified for EGFR-targeting immunotherapies, concurrently comparing the therapeutic efficacies of the different treatment modalities and conclude on future perspectives.

\section{BRIEF OVERVIEW OF EGFR-SPECIFIC IMMUNOTHERAPEUTICS}

\section{The evolution of antibody-mediated therapeutics}

Cancer treatment is traditionally founded on three approaches; surgery, radiation and chemotherapy, which have shown limited therapeutic benefits in patients 
with metastatic disease $[43,44]$. Despite the significant advances in the development of systemic treatment over the years, the therapeutic usage of toxic agents is a twoedged sword potentially causing normal organ toxicities, thus restricting treatment to certain therapeutic dosages [9]. In light of this, novel palliative treatment approaches were urgently needed to specifically treat patients with refractory and metastatic disease. Although a full discussion is outside the scope of this review, it suffices to say that cancer immunotherapy-in the form of adoptive cell therapy (ACT) - is an alternative therapeutic option, using the patient's own immune system to control and destroy tumor cells $[45,46]$. This therapeutic modality relies on antigen recognition of tumor cells by antigen presenting cells (e.g., dendritic cell) or engineered cytotoxic T-lymphocytes (e.g., chimeric antigen receptor T-cells) to specifically recognize and induce tumor destruction in an antigen-dependent manner [44-50]. Despite their initial clinical success, immune cell-based therapies have been limited in treating solid tumors due to T-cell exhaustion or their incapacity to infiltrate tumors.

To target receptors on solid tumors, tumorspecific mAbs binding to oncogenic cell surface receptors were developed as a form of molecular targeted immunotherapeutic treatment. Traditionally, this naked antibody-based immunotherapy induces tumor destruction through ADCC, complement-dependent cytotoxicity (CDC) or receptor blockade [29, 51-53]. Demonstration of the therapeutic potential of mAbs was performed using cetuximab (anti-EGFR mAb), which successively induces EGFR-specific tumor destruction through receptor blockade, subsequently causing EGFR endocytosis and inhibition of intracellular tyrosine kinase function regulating downstream pro-tumorigenic signals $[54,55]$. To achieve this therapeutic goal, cetuximab has shown to trigger apoptosis by impairing the cell cycle, reducing angiogenesis, tumor cell invasion, metastases and activating an antitumor immune response [56, 57]. The most notable clinical success using ErbB-mAbs leading to FDA approval was accomplished using trastuzumab (Herceptin, 1998, breast cancer targeting HER2) and cetuximab (Erbitux, targeting HER1 or EGFR) which significantly prolonged head and neck squamous cell carcinoma (HNSCC) patient survival (from 29.3 to 49 months) when combined with chemo- (Cisplatin or carboplatin and 5-Fluorouracil) and radiotherapy $[58,59]$. Likewise, another anti-EGFR IgG2 mAb, panitumumab (Vectibix), was FDA approved (September 2006) as a first-line or palliative therapy (following chemotherapy using fluoropyrimidine, oxaliplatin and irinotecan) to treat metastatic colorectal cancer patients $[14,60$, 61]. This regimen was clinically approved as it offered superior patient survival (96.4 vs 59.7 days), than the best supportive care treatment alone [14, 62]. Similarly, pertuzumab (2012: anti-HER2), and necitumumab (2015: anti-HER1) were FDA approved for treating HER2- positive breast and EGFR-positive non-small lung cancers (NSLCs), respectively [14, 19-26]. Despite their encouraging initial responses, their widespread application against tumor associated antigens (TAAs) was limited to a combination with immune checkpoint inhibitors only, as they did not offer significant therapeutic benefits against known preclinical animal xenograft models of human cancers [63-65]. Although simple enough in concept, their therapeutic application (mAbs) has been beset with multiple obstacles, owing to a combination of various factors including: (1) non-specific biomarker selection enabling the identification of irrelevant target tumor antigens; (2) inefficient potency of naked $\mathrm{mAb}$ as anticancer drugs; (3) poor tumor cell penetration of mAbs; (4) production of neutralizing antibodies (or antiidiotypic antibody) against mAbs of human origin; and (5) off-target effects and immunogenicity when used in humans with functional immune systems, limiting repeated treatment dosage schedules $[28,66,67]$. These undesirable effects were reported to cause skin and cardiac toxicities, when treating colorectal and breast cancer patients with cetuximab, panitumumab and trastuzumab $[62,68,69]$. Collectively, these mAbs have the capacity to activate a human immune response able to neutralize administered human-mAbs (anti-idiotypic antibody) and alter their therapeutic efficacy $[67,70,71]$. The mitigation of these undesired effects, was rendered possible with the advent of DNA technology which led to the chimerization and humanization of antibodies able to reach clinical fruition [72].

\section{Chimeric, humanized, and generation of new Ab formats using recombinant DNA technology}

Monoclonal antibodies (mAbs) of the $\operatorname{IgG}$ isotype subtype are the most commonly used in immunotherapeutic treatment and are typically made of four polypeptides consisting of two heavy and light chains which are covalently linked together by disulphide bonds to form a "Y" structure (see Figure 1A). The tips of the heavy-light chain pairs form the antigen-binding domain (Fab) which is subdivided into seven amino acids, four of which are the framework regions (FRs) and three of which are the primary antigen recognition site known as complementarity-determining regions (CDRs) [9, 28]. On the other hand, each heavy chain is made up of three constant domains namely $\mathrm{CH} 1, \mathrm{CH} 2$, and $\mathrm{CH} 3$, as well as one variable domain $\left(\mathrm{V}_{\mathrm{H}}\right)$, while each light chain consists of one constant domain $\left(\mathrm{C}_{\mathrm{L}}\right)$ and one variable domain $\left(\mathrm{V}_{\mathrm{L}}\right)$ (Figure 1A). The antibody effector function is mediated by the fragment crystallizable $(\mathrm{Fc})$ within the heavy chain constant region $[52,73]$. The assembly of these domains is critical for normal antibody function. In light of this, antibody chimerization was developed with the intent to reduce mAbs immunogenicity, enable multiple dosing schedules and favoring assessment of their 
pharmacokinetic behavior and host immune activating function [74]. Chimerization is a transgenic manipulation consisting of fusing a murine-derived antibody variable region domain (Fab: antigen binding properties) with a human $\mathrm{IgG}$ constant region (Fc) possessing the effector functions that mediate ADCC (Figure 1A) [52]. Despite the clinical success and regulatory approval of these chimeric antibodies (e.g., Rituximab, FDA approved in 1997), they still possessed some human anti-mouse antibody (HAMA) responses [75]. Therefore, the next intuitive step in improving chimeric antibody properties led to humanization of the fragment variable regions (Fab) possessing antigen binding activity.

With the advent of recombinant DNA technology, $\mathrm{mAb}$ humanization consisting of grafting a murine CDR into a CDR depleted human IgG was performed. Using this grafting method, the anti-HER2 humanized antibody trastuzumab was produced and FDA approved in 1998 to treat HER2-positive cancers (breast, pancreas, and nonsmall cell of lung cancer) [76]. This humanized antibody was more potent than its murine counterpart and standard chemotherapy, based on its ability to efficiently activate ADCC [63, 77-81]. Other humanization procedures include veneering which relies on FRs manipulation [63, 77-81]. However this approach may seriously impair mAbs antigen binding capacity, which heavily relies on the topography and chemical structure of the CDRs and some FRs to maintain its binding affinity [78, 81]. These limitations paved the way to the development of transgenic mice, which enabled the production of fully human antibodies. These mice were engineered to possess functional human immunoglobulin transgenes, by replacing their mouse orthologues that were genetically inactivated $[63,80]$. Once produced after immunization, such human $\mathrm{mAb}$ could be cloned and scaled up using hybridoma technology. For example, E7.6.3 mAb which specifically targeted EGFR was produced using this method [82]. During this study, E7.6.3 mAb was strongly binding to its cognate receptor and this binding was correlating with decreased cell viability and tumor eradication in mice, which showed no signs of recurrence up to 8 months after the last injection [82]. Nevertheless, human mAbs may acquire somatic mutations during their maturation process in transgenic mice within their FR and CDR regions [83]. Consequently these mAbs will no longer share complete sequence homology to their inherent human germline, which may predispose them to immunogenic reaction in humans $[63,83]$. Because of these biotechnological advances, mAbs are starting to fulfill their therapeutic role as immunotherapeutic agents. Of late, antibody genetic engineering has enabled the production of genetically truncated versions of an antibody, deprived of their constant regions (Figure $1 \mathrm{~B}$ and $1 \mathrm{C})$. These new antibody formats, rely on the assembly or randomization of CDRs of the fragment variable regions, which still possess their antigen binding properties and can be genetically fused to fusion proteins or cytotoxic payloads $[78,81,84,85]$. These non-natural antibody fragments are of interest, since they have shown their potency in treating multiple malignancies, when genetically assembled in a specific manner [70, 78, 82, 83]. To this effect, various single chain fragment variable regions (scFvs) of about $30 \mathrm{kDa}$ and consisting of the variable domain of the heavy and light chain $\left(\mathrm{V}_{\mathrm{H}}+\mathrm{V}_{\mathrm{L}}\right)$ of a mAb linked by a short peptide sequence have shown their efficacies in diagnosing and treating various diseases including cancer (Figure 1C) [74, 81, 86-88].

Variable region genes of immunoglobulins can be re-assembled into multivalent antibodies with improved avidity to their target antigen. For example, diabodies of about $60 \mathrm{kDa}$ can be derived from scFv fragments through engineering of their interdomain linkage; introducing a peptide with maximally five amino acids favors interchain pairing to form a dimer, while preventing intradomain linkage between $\mathrm{V}_{\mathrm{H}}$ and $\mathrm{V}_{\mathrm{L}}$ of the same chain [39, 86, 88, 89]. Furthermore, assembly of $\mathrm{scFv}$ into trimers $(90 \mathrm{kDa})$ and tetramers $(120 \mathrm{kDa})$ can be achieved by further reducing the length of the linker, which will ultimately increase avidity and affinity. As Fc domains are missing in these antibody formats, the cytotoxic effects cannot be driven by ADCC or CDC but could be achieved through receptor or signaling blocking and thus either obstructing the interaction between the growth factor and their target receptor or by activating downstream molecular signaling regulating cell division and cell death program $[74,81]$.

To conserve and expand these attributes, bispecific $\mathrm{scFv}$ fragments were re-engineered by joining four mAbs variable domains $\left(\mathrm{V}_{\mathrm{H}}\right.$ and $\left.\mathrm{V}_{\mathrm{L}}\right)$, recognizing two different epitopes into a single chain construct. These bispecific antibodies are endowed with the capacity to recognize two different antigens, allowing cross-linkage of two different cells such as cancer cells and immune cells (e.g., T-lymphocytes, macrophages, or NK cells) [74, 86].

Altogether, these new antibody formats do have different characteristics to be exploited as therapeutic agents when compared to their mAb counterparts. These recombinant antibody formats can: (1) be genetically modified; (2) produced in different hosts of expression; and have the potential to (3) extravasate more efficiently; and (4) penetrate deeper into tumor tissue [70]. Yet, smaller size can be a limiting factor reducing their half-life in serum, due to kidney clearance filtering out molecules smaller than $60 \mathrm{kDa}$ from blood and excreting them in urine [74]. Therefore, the multimerization might become a potential alternative to overcome this prematured excretion. Independently, protein engineering and applied chemistry is allowing to further functionalize these recombinant antibody formats by cytotoxic small molecule drugs or proteins $[90,91]$. 


\section{Selected examples of a directed antibody-drug conjugation method}

\section{Site-specific sortase-mediated enzyme conjugation of monoclonal antibodies to cytotoxic payloads}

Sortase A is a transpeptidase enzyme found within the $S$. aureus gram-positive bacteria. Sortase A induces catalysis by forming an amide bond between the threonine of the C-terminal pentapeptide (LPXTG) and the glycine at the N-terminus of the conjugation partner $[56,58]$. During this transpeptidation reaction, sortase-A recognizes the C-terminus (LPXTG) sequence, cleaves the TG bond and consequently exposes the threonine to nucleophilic attack to the incoming alpha amine, which is preferably the glycine on the $\mathrm{N}$-terminal of the conjugation partner via a thioacyl enzyme threonine intermediate $[92,93]$. Recently, the antibody moiety of two ADCs (Adcetris) and trastuzumab-maytansine (Kadcyla), were used as model
mAbs in the generation of sortase-conjugated ADCs [94]. These ADCs were generated through C-terminal modification of immunoglobulin heavy (IgH, anti-CD30) and light chain (IgL, anti-HER2), with sortase A enzyme recognition pentapeptide sequence (LPETG) on the targeted domain and the modification of the monomethyl auristatin E (MMAE) and maytansine payloads with pentaglycine peptide $[57,94]$. Once produced, these ADCs were shown to have a higher in vitro killing efficacy in comparison to their non-enzymatically modified counterparts. Of note, sortase-conjugated trastuzumabmaytansine was shown to completely eradicate tumor growth in xenograft mouse models injected with HER2overexpressing ovarian cancer cells [91]. Nevertheless, sortase A had a disadvantage since its transpeptidation reaction is limited to the $\mathrm{C}$ and $\mathrm{N}$ termini of an amino acid within the pentapeptide [94]. Based on these limitations, newer conjugation methods were developed using self-labeling proteins such as Halo, CLIP and
A

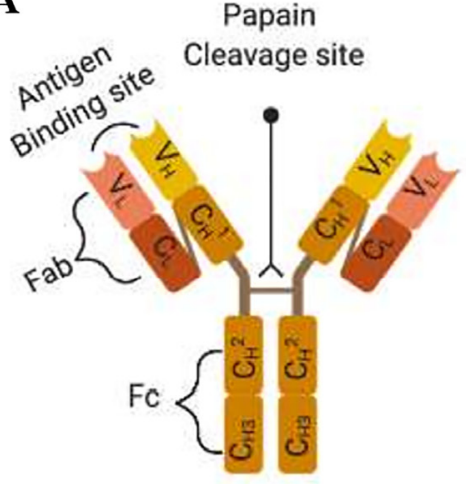

$\mathrm{C}=$ Constant domain

$\mathrm{V}=$ Variable domain

$\mathrm{H}, \mathrm{L}=$ Heavy and light chains
B

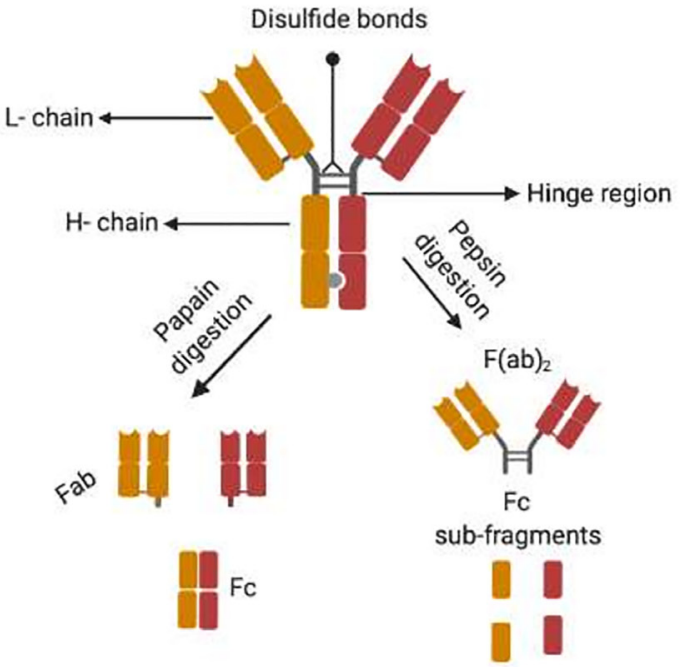

C
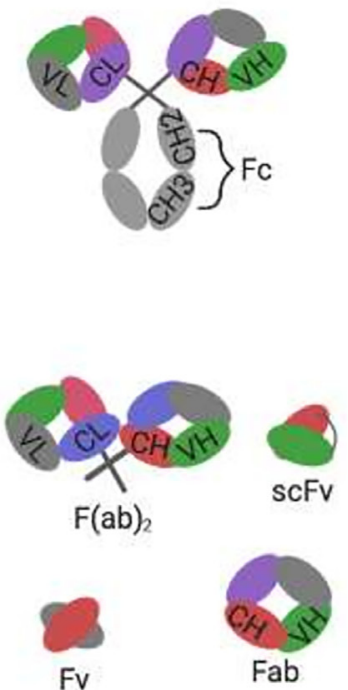

Figure 1: Alternative formats of engineered human antibodies. (A) Domain organisation of an IgG molecule; (B) separation of antibody function by proteolytic cleavage; (C) schematic representation of multivalent recombinant antibody constructs. 
SNAP-tag offering a unique conjugation site on the antibody, enabling the production of homogeneous ADC conjugates [56].

Halo, CLIP, and SNAP-tag specific conjugation methods to generate antibody-fusion proteins

Halo-Tag is an engineered version of a bacterial haloalkane dehalogenase, which is designed to rapidly and specifically react with chlorohexane-modified substrates (e.g., fluorescent dyes, affinity handles or solid surfaces), hence forming irreversible covalent bonds under physiological conditions [59, 95, 96]. Its non-human origin implies immunogenicity, in contrast to CLIP-tag and SNAP-tag which are both improved mutant versions of the human DNA repair enzyme $\mathrm{O}^{6}$-alkylguanine-DNA alkyltransferase (AGT) which naturally reacts with $\mathrm{O}^{6}$ benzylguanine derivatives [94, 96, 97]. This AGT labeling property was primarily performed through a reaction with the $\mathrm{O}^{6}$-benzylguanine $(\mathrm{BG})$ derivative, resulting in an irreversible transfer of the BG-modified substrate to cysteine within the active site of AGT [97-99]. Subsequently, this AGT activity was improved through saturation mutagenesis experiments, which increased the AGT mutant activity by 20 -fold in comparison to the wild-type [98]. Thereafter, several mutations were introduced on AGT to abrogate its DNA binding capacity, and render it resistant against inhibitors of wild-type AGT [61]. These mutations led to a reduction of the AGT size (182 residues), through the deletion of non-essential cysteine residues, which eases the folding of the mutant AGT under oxidizing conditions [100]. In summary, these mutations led to the generation of 'suicidal enzymes' such as CLIP-tag which can react specifically and rapidly with $\mathrm{O}^{2}$-benzylcytosine derivatives (BC-derivatives) and form an irreversible covalent bond between $\mathrm{BC}$-ligands and cysteine residues within the CLIP-tag active site of the fusion protein. Therefore, CLIP-tag can be used as a selflabeling conjugation method for visualization of fusion proteins in living cells, as well as for enzyme-linked immunosorbent assays, western blotting, flow cytometry and immunohistochemistry [101, 102].

SNAP-tag is a self-labeling enzyme, resulting from an engineered version of the $20 \mathrm{kDa}$ human DNA repair protein AGT that specifically and rapidly reacts with BG derivatives. SNAP-tag has a 50-fold increased reactivity with BG-modified compounds when compared to AGT, which under normal conditions functions to remove alkyl adducts from the $O^{6}$ and the $O^{4}$ positions of guanine and thymine to protect cells from the potent effects of alkylating agents [101, 103]. Hence, SNAP-tag performs a nucleophilic substitution reaction resulting in an irreversible, covalent coupling of BG-modified substrates, such as a fluorochrome, PS, or small molecule toxin with the thiol group of Cysteine 145, within the active site of the SNAP-tag molecule [103, 104] (Figure 2). Therefore SNAP is a simple conjugation method which ensures:
(1) specificity of conjugation (reacts only with BGmodified substrates); (2) shorter conjugation reaction (30 minutes for BG-fluorochromes and 2 hours for cytotoxic payloads); (3) flexibility of expression system (bacteria, yeast, or mammalian), availability of various BG-modified substrates; (4) no reactivity with other cellular substrates; (5) no requirement for activating substrates for the conjugation reaction; and (6) a 1:1 stoichiometric reaction generating homogeneous products by only reacting with BG-molecules [88, 89, 98, 104-106].

\section{ANTIBODY-DRUG-CONJUGATES TARGETING EGFR}

Antibody-drug-conjugates (ADCs) emerged as a promising therapeutic modality prepared from naked antibodies by chemically or enzymatically conjugating a cytotoxic payload using specific linker chemistries. Most currently, cytotoxic molecules are too toxic for systemic application, thus ADCs provide a method to harness the specificity of a mAb for targeted delivery of such highly potent cytotoxic agents to tumor cells expressing a unique cognate antigen $[89,91,97,104,107,108]$. According to the generally accepted mechanism of action, binding of an ADC to such a tumor associated cell surface antigen, induces internalization of the ADC-antigen complex into the targeted cell by receptor-mediated endocytosis and subsequent trafficking of the ADC-loaded endosomes to the lysosomal compartment (Figure 3). Once in the lysosomes, the payload is released through enzymatic digestion or a $\mathrm{pH}$-induced degradation of the linker, causing cytosolic release of the cytotoxic payload to efficiently induce cell death [109].

The propensity of ADCs mainly depends on the nature of the mAbs, the linker, and the cytotoxic payload, which synergistically work to exert their maximal toxicities [30, 110-112]. For instance, the chemical nature of the linker which joins the mAb to the cytotoxic payload may negatively affect ADCs' biophysical properties, hence their potency $[113,114]$. The latter was corroborated by Lewis Philips et al. (2008) reporting an improved therapeutic efficacy, pharmacokinetics behavior and reduced toxicity when HER2-positive breast cancer tumor xenografts were treated with a non-reducible thioether linker-based trastuzumab-maytansinoid conjugate as opposed to its counterpart that had a reducible disulfide linker [111]. Moreover, the hydrophobic nature of most potent ADCs may reduce their therapeutic efficacy as a result of $\mathrm{mAb}$ aggregation and precipitation [112]. To address this issue, various iterations were performed using solubilizing agents and linkers containing poly (ethylene) glycol chains of various lengths which are compatible with buffered mAbs [9]. So far, 8 ADCs including Gemtuzumab ozogamicin (Mylotarg), Brentuximab vedotin (Adcetris), Trastuzumab emtansine (Kadcyla/T-DM1), Inotuzumab 
ozogamicin (Besponsa), Polatuzumab vedotin-piiq (Polivy), Enfortumab vedotin (Padcev), Trastuzumab deruxtecan (Enhertu), and Sacituzumab govitecan (Trodelvy) have received FDA approval for cancer treatment [115]. Additionally, AMG-595 and depatuxizumab mafodotin (Depatux-m), both targeting EGFR VIII overexpressing glioblastoma multiform (GBM), were developed and improved therapeutic efficacy when treating GBM in both preclinical and clinical studies, through specific intracellular delivery of cytotoxic anti-microtubule agents such as maytansinoid or monomethyl auristatin F (MMAF) [116]. Conventionally, ADCs are generated through chemical conjugation (alkylation or acetylation) of lysine, or reduced inter-chain disulphide residues of mAbs to cytotoxic payloads [117122]. In 2014, an orphan drug status (assigned to a medicine intended for use in rare diseases) was given by the FDA to Depatux-m also known as ABT-806 [94, 111, 123]. Depatux-m consists of an IgG1 humanized antibody, conjugated to MMAF using a non-cleavable linker maleimidocaproyl [120-122, 124]. This ADC targets a unique EGFR epitope variant (EGFR VIII), which is genetically deprived of exons 2 to 7 and commonly found in GBM, the most common form of malignant brain cancer [120-122, 124, 125]. EGFR VIII defines a unique epitope lacking an ectodomain and is associated with GBM poor prognosis (a median survival of about 16 months upon diagnosis), caused by constitutive activation of its intracellular tyrosine function [120-122, 124, 126]. Under normal physiological conditions, EGFR VIII is not accessible and not expressed on normal cells [120, 121, 123]. This makes it an ideal biomarker, limiting the undesirable side effects associated with ADCs. The results of several pharmacological studies revealed that a drug-toantibody ratio (DAR) of 4 was required for depatux-m to significantly reduce tumor growth both in preclinical and clinical studies [121, 122, 124]. Interestingly, Depatux-m was shown to bind EGFR VIII with higher affinity than cetuximab and to synergistically increase therapeutic efficacy when combined with standard care therapies (e.g., Cisplatin, 5-FU and temozolomide) when treating GBM and HNSCC $[117-122,127]$. Depatux-m has passed phase I clinical trial and its efficacy is presently being assessed in phase II/III clinical trials on EGFR overexpressing GBM patients (NCT02343406, NCT02573324). These results spurred the development of other EGFR specific ADCs such as AMG-595, consisting of a fully human EGFR IgG1 mAb linked to the antimitotic agent maytansinoid DM1 via a non-cleavable maleimidomethyl cyclohexane-1-carboxylate (MCC) linker [121]. According to Hamblett et al. (2015), AMG-595 exclusively binds to and kills EGFR VIII expressing GBM both in in vitro and in preclinical orthotopic mouse xenograft models using a DAR of about 3.5 [128]. Recently, Rosenthal et al. (2019), have shown during a phase I clinical trial that AMG-595 was safe to treat GBM patients overexpressing EGFR VIII [128]. According to this phase I trial, 47\% and 6\% of patients respectively had a stable disease (17 out of 32 ) and a partial response ( 2 out of 32 ) correlating with a dose-dependent increase of conjugated products in plasma and a very low level of unconjugated antibody and cytotoxin [126]. Regardless of these therapeutic successes, multiple factors such as the type of linker must be taken into consideration to predict the clinical efficacy of ADCs, as unstable linkers and ADC recycling by the neonatal Fc receptor $(\mathrm{FcRn})$ upon internalization, have the capacity to prolong their systemic circulation which can potentially cause side effects [126]. Other factors including DAR have shown to negatively impact the pharmacokinetic behavior of ADCs, and the therapeutic outcome due to generation of heterogeneous ADC products, which can aggregate and precipitate in virtue of the payload hydrophobic properties $[30,125,129,130]$. This has been mitigated by the use of solubilizing agents [9]. Interestingly, a DAR of 4 was found to reduce the presence of unconjugated antibody and maintain the half-life circulation of ADCs [131-134]. On the other hand, a DAR of 8 showed to cause ADC deterioration, increase premature clearance from bloodstream and aggregation capacity, which induces an immunogenic reaction as a result of the hydrophobic nature of the payloads, while reducing their stability under stress conditions [31]. Contradicting results using similar DAR (8) were recently published by Iwata et al. (2018 and 2019), showing the antitumor efficacy of trastuzumab deruxtecan (Humanized anti-hHER2 conjugated with the topoisomerase I inhibitor

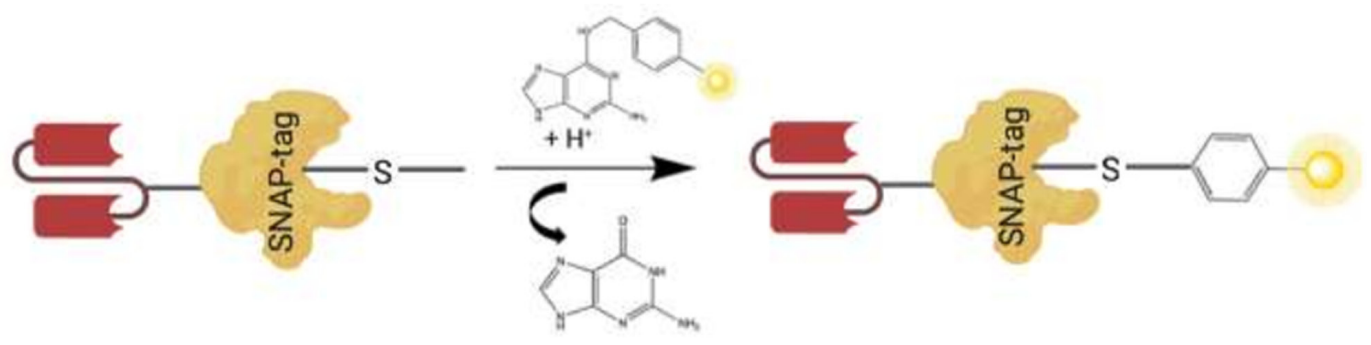

Figure 2: A schematic illustrating scFv-SNAP fusion protein conjugated to a BG modified substrate. Autocatalytic reaction of BG modified substrate (e.g., photosensitizer, fluorochrome, or small molecule toxin in yellow), with the thiol group of cysteine 145 within the active site of SNAP-tag genetically fused to amino acid terminus of $\mathrm{V}_{\mathrm{L}}$ chain of the scFv. 
exatecan derivative DS-8201) using a mouse model of colon and breast cancers overexpressing HER2 receptor $[135,136]$. DS-8201 was exerting its therapeutic efficacy by specifically killing HER2 expressing tumors and increasing tumor infiltrating dendritic cells, $\mathrm{CD}^{+}$and $\mathrm{CD}^{+}$T-cells in vivo $[137,138]$. Of late, DS-8201 has gained FDA approval (December 2019), and has clinically shown its efficacy in treating various malignancies including: breast, gastric, gastro-esophageal, colorectal, salivary, and non-small cell lung cancers [130, 137-140]. The success of DS8201, was based on improved therapeutic properties including: good homogeneity of high DAR, tumor selective cleavable peptide linker, with increased linker-payload serum stability and short half-life of the toxic-warhead [141]. Furthermore, the nature of the linker, which covalently connects the cytotoxic payloads to the $\mathrm{mAb}$ is crucial as it may significantly impact ADC activities. The ideal linker should be stable enough to maintain the cytotoxic payloads attached to the mAb and only release it once internalized within cancer cells [30, $110,123,142]$. Inevitably, one needs to critically evaluate the linker design, prior to the engineering of an ADC. Two classes of ADC linkers can be distinguished based on their capacity to be cleaved or not, once internalized within the target cells [110, 143]. Among the cleavable linkers, multiples subtypes such as acid labile linkers (e.g., hydrazine linkers), were used to produce the FDA approved Gemtuzumab ozogamicin. These hydrazine linkers are $\mathrm{pH}$ sensitive and usually dissociate from mAbs through hydrolysis in lysosome-like microenvironmentsvery acidic — or hypoxic tumor regions [56, 93, 144].
Other forms of cleavable linkers include valine-citrulline dipeptides and disulphide linkers, which respectively rely on enzymatic cleavage (e.g., cathepsin B, cysteine protease) under acidic lysosomal conditions and high level of reduced glutathione $[31,145]$. Conversely to cleavable linkers, non-cleavable linkers are inherently stable in plasma with reduced side effects, which favor repeated treatment cycles $[31,110]$. It then ensues that the type of chemical conjugation of the payloads to ADCs are very critical, as they significantly influence ADC stability, clinical efficacy, DAR and pharmacokinetic behavior [137, 146]. Examples of non-cleavable linkers include lysine or cysteine amino acid conjugations, which tend to generate different DARs or necessitate partial cysteine reduction [31, 147]. Lately, efforts to improve ADCs homogeneity through site-specific conjugation of mAbs to toxic payloads, have been performed using SNAP-tag technology.

\section{EGFR-targeting SNAP-tag based antibody fusion proteins}

Lately, SNAP-tag was used to generate several recombinant antibody-based fusion proteins for photoimmunotheranostic (PIT) and ADC-based treatments in melanoma, ovarian and breast cancers $[31,39,88,89$, 107, 111, 148]. EGFR expressing tumors were selectively killed by conjugating specific scFv-SNAP fusion proteins to near infrared PSs (such as IR700) or auristatin F (MMAF/AURIF) [39, 83, 84, 106, 139]. Binding and internalization of the anti-EGFR immunoconjugate

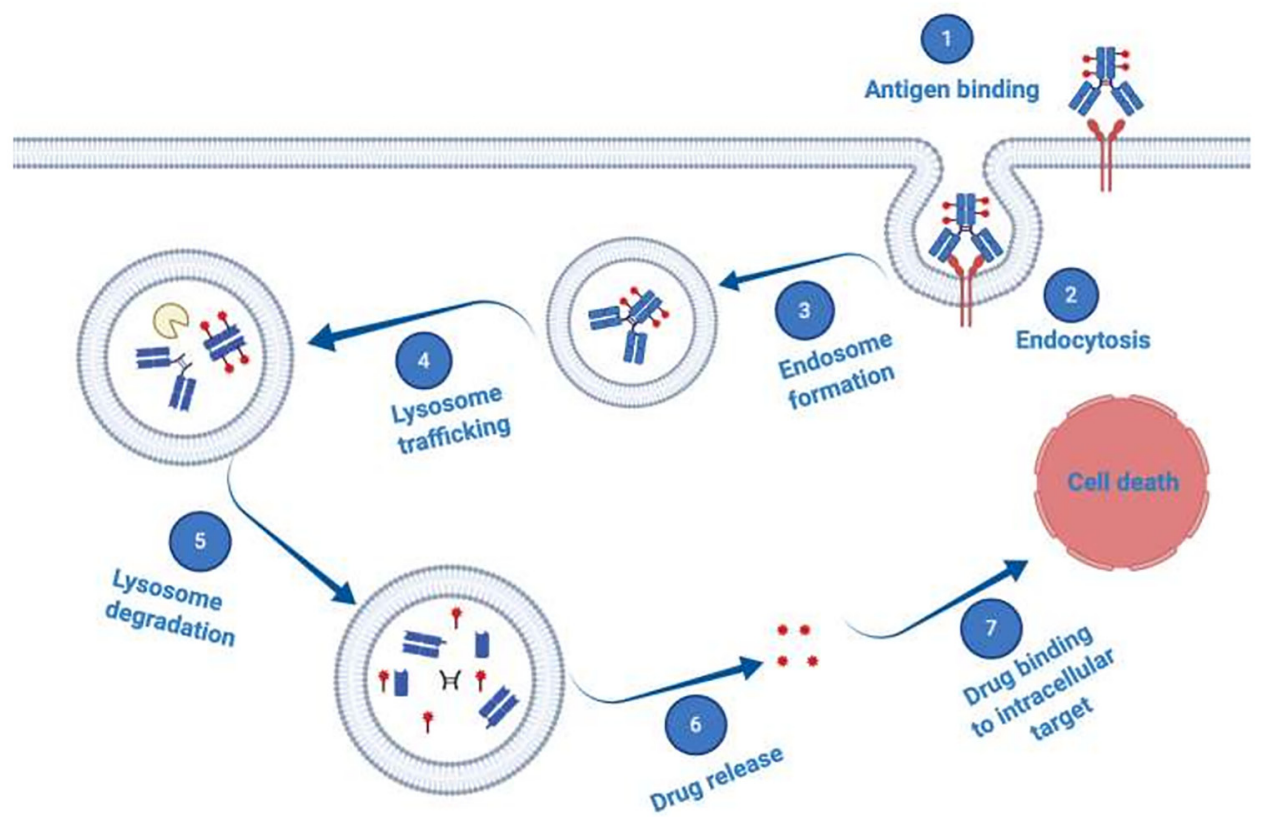

Figure 3: Schematic illustration of antibody-drug conjugate (ADC) mechanism of action. ADCs consist of a mAb which is attached to a synthetic cytotoxic drug through a specific chemical linker. The mAb binds to a disease-specific cognate tumor associated antigen overexpressed on target cells, is internalized via endocytosis and trafficked to the lysosome, where proteases degrade the ADC. Thus, the cytotoxic cargo becomes released and diffuses into the cytoplasm to reach its intracellular targets and induce cell death. 
425( $\mathrm{scFv}$ )-SNAP-AURIF was confirmed on EGFRexpressing target cells confirming that conjugation to MMAF (or AURIF) did not influence the binding activity of the fusion protein as expected, since the active site of SNAP-tag is structurally opposed to the paratope of the scFv [39, 88, 89, 107, 149]. Additionally, while unconjugated BG-AURIF was toxic to all cell lines, 425(scFv)-SNAP-AURIF did not affect the viability of EGFR-negative A2058 control cells [149]. This implies that the specificity and functionality of the antibody moiety is still retained. In contrast to auristatins which are known to show cytotoxicity in the lower nanomolar range $(\sim 1 \mathrm{nM})$ [149], the authors were able to show comparable cytotoxicity, ranging from 3-21 nM (based on the cell line), indicating that AURIF retained its anti-tumor activity even after being BG modified [150]. Furthermore, the stability of ADCs in circulation is critical to limit side-effects caused by systemic application and 425( $\mathrm{scFv}$ )-SNAP-AURIF was able to maintain at least $50 \%$ of its initial cytotoxicity after 48 hours incubation in serum [149]. Selective binding to EGFR-positive breast cancer and other overexpressing tumor cell lines described for 425(scFv)-SNAP-AURIF and panitumumab-derived 1171(scFv)-SNAP-AURIF, was also confirmed on EGFRpositive breast cancer biopsies [149]. A DAR of 1 in these types of recombinant SNAP-tag based ADCs (Table 1) may be explored to further increase the efficacy of ADCs by novel synthetic chemistries without abrogating binding activity [107]. In conclusion, SNAP-tag allows the stable and efficient linkage of AURIF to recombinant antibody fragments, thus offering a promising avenue to improve the development of personalized medicines [149]. For these reasons, the use of SNAP-tag fusion proteins as a targeted therapeutic approach, might become a pertinent choice in combating chemotherapy-resistant cancers.

\section{EGFR-TARGETING ANTIBODY PHOTOIMMUNOCONJUGATES}

\section{Near-infrared photoimmunotherapy}

Near-infrared photoimmunotherapy (NIR-PIT) can be defined as the targeted version of photodynamic therapy (PDT), an FDA-approved anti-cancer modality using a light-activated compound known as a PS, to produce death-inducing amounts of reactive oxygen species (ROS), causing tumor destruction through apoptosis, necrosis, vasculature damage, and initiation of acute local and systemic inflammation (Figure 4) [107]. As opposed to PDT, NIR-PIT utilizes the specificity of a tumor-specific mAb conjugated to a PS (e.g., phthalocyanine dye IR700) to induce phototoxicity after NIR light exposure (e.g., $690 \mathrm{~nm}$ ) [9, 144, 151, 152]. Recently, multiple in vitro studies have shown the specificity and efficacy of NIRPIT in killing targeted cancer cells using sub-nanomolar concentration ranges of the PS which were non-toxic to healthy neighboring cells (Table 2) [42, 88]. Similarly, numerous preclinical human xenograft models of breast, melanoma, glioblastoma, ovarian, and pancreatic cancers have shown the combined potent therapeutic and diagnostic effects of NIR-PIT in reducing tumor growth [7, 10, 39, 41, 86, 144-146]. For instance, Burley et al. (2018), showed that reduction in cellular proliferation and GBM tumor growth could be achieved using EGFR VIII-targeted NIR-PIT [9, 12, 39, 41, 91, 153-155]. This result was conforming with Ito et al. 2016 study, showing the synergistic potential of trastuzumab and pertuzumab-targeted NIR-PIT (using IR700) in reducing HER2-overexpressing breast and gastric tumors [155]. Comparable effects were obtained by Nakajima et al. (2013), when combining panitumumab-IR700 with basiliximab-IR700 (interleukin-2 receptor alpha CD45) to targeted cancer cells expressing these receptors [154]. Also, Sato et al. (2014) showed that panitumumab-IR700 was more efficient than cetuximab-IR700 in killing EGFR overexpressing tumors [41]. This differential in vitro therapeutic efficacy was associated with faster hepatic catabolism and poor cetuximab-IR700 tumor penetration when compared to panitumumab-IR700 [12]. Besides, Saxena et al. (2015), revealed that post-operative NIRPIT could significantly reduce both local and metastatic pancreatic tumor recurrence, when compared to bright light surgery (BLS) which displayed bigger tumor volume $\left(115.2 \mathrm{~mm}^{2}\right)$ than its counterparts $\left(2.14 \mathrm{~mm}^{2}\right)$ [12]. The preclinical success of these studies paved the way for the first cetuximab-IR700 human clinical trial which has reached phase III and is presently being tested for the treatment of advanced head and neck cancer patients with recurrent disease (NCT03769506) [40].

\section{Photoimmunotheranostic treatment}

Photoimmunotheranostic treatment is a new treatment strategy combining the diagnostic and tumor shrinkage properties of antibody photoimmunoconjugates (APCs), which specifically accumulate into targeted tumors and induce their selective destruction upon irradiation with a specific light source (Figure 4) [9, 156-160]. This novel cancer treatment approach offers promising opportunities in improving cancer detection and monitoring post-treatment responses [161]. Taking this into consideration and using SNAP-tag technology, von Felbert et al. were able to specifically visualize and kill skin cancer cells in vitro using a panitumumabderived SNAP-IR700 showing $\mathrm{IC}_{50}$ values of $32-55 \mathrm{nM}$ (Table 2) [11]. These results were supported by reports from Amoury et al. (2016) and Bauerschlag et al. (2016) demonstrating the use of SNAP-tag conjugates for the detection of tumor sections in ovarian and breast cancer tumor biopsies (overexpressing CSPG4, EGFR, and EpCAM) using fluorescence immunohistochemistry and the induction of targeted killing with $\mathrm{IC}_{50}$ values 
of 45-90 $\mu \mathrm{M}$ and 62-165 $\mu \mathrm{M}$, respectively (Table 2) [89]. Of note, triple-negative breast cancer (TNBC) is the most aggressive form of breast cancer comparably resistant to conventional therapies and cannot benefit from hormone therapies due to absence of corresponding receptors [88]. TNBC therapeutic resistance has partly been associated to a therapeutic resistant subpopulation overexpressing CD44. Hence, using theranostic treatment, Jin et al. (2016) were able to specifically detect and destroy CD44-expressing tumors in a human xenograft tumor model [144]. This targeted regimen is of particular clinical relevance, since it can reduce post-operative residual TNBC tumors using image-guided surgery or specifically treat therapy resistant primary tumors [153]. Interestingly, a study led by Ogata et al. (2017) revealed the superiority of repeated NIR-PIT ( 2 or 3 times on the same day) in significantly reducing tumor growth and prolonging overall survival compared to single treatment [153]. Although only demonstrated in animal models, this therapeutic regimen should be more effective and more economically viable for patients, who would only require a single dose of APC, followed by multiple irradiation doses to achieve greater tumor responses [11]. Currently the preferred regimen consists of injecting APCs 24 hours before the first irradiation. Thus, this implies that a second or third irradiation would activate circulating APCs, which did not previously accumulate within the tumor [11]. With this in mind, Harmatys et al. developed a long circulating pyropheophorbide (LC-Pyro) immunoconjugate (conjugate to prostate specific membrane antigen) with a trifunctionality capable of screening tumors using fluorescent imaging and positron-emission tomography (PET) [162]. Using this LC-pyro immunoconjugate, this group was able to diagnose tumors in orthotopic, subcutaneous and metastatic murine animal models [162]. Upon light activation, the LC-pyro immunoconjugate was able to significantly increase overall survival (over 40 days) when compared to the unirradiated control (24 days) [162].

\section{EGFR-SPECIFIC \\ RECOMBINANT IMMUNOTOXINS}

\section{Anti-EGFR immunotoxins in cancer therapy}

The development of immunotoxins (ITs) was the logical consequence of an alternative strategy to antibodydriven chemotherapeutics, based on the speculation that replacing inefficient synthetic warheads by protein toxins with enzymatic activity should theoretically allow to kill cells with only a few effector molecules released within the target cell [162]. ITs are potent molecules consisting of a protein toxin linked to a binding ligand such as an antibody or a growth factor [163]. Whereas the first generation of ITs was based on chemical conjugation, successive generations were primarily recombinant versions with higher specificity, reduced toxicity and improved tumor penetration, while also ensuring large-

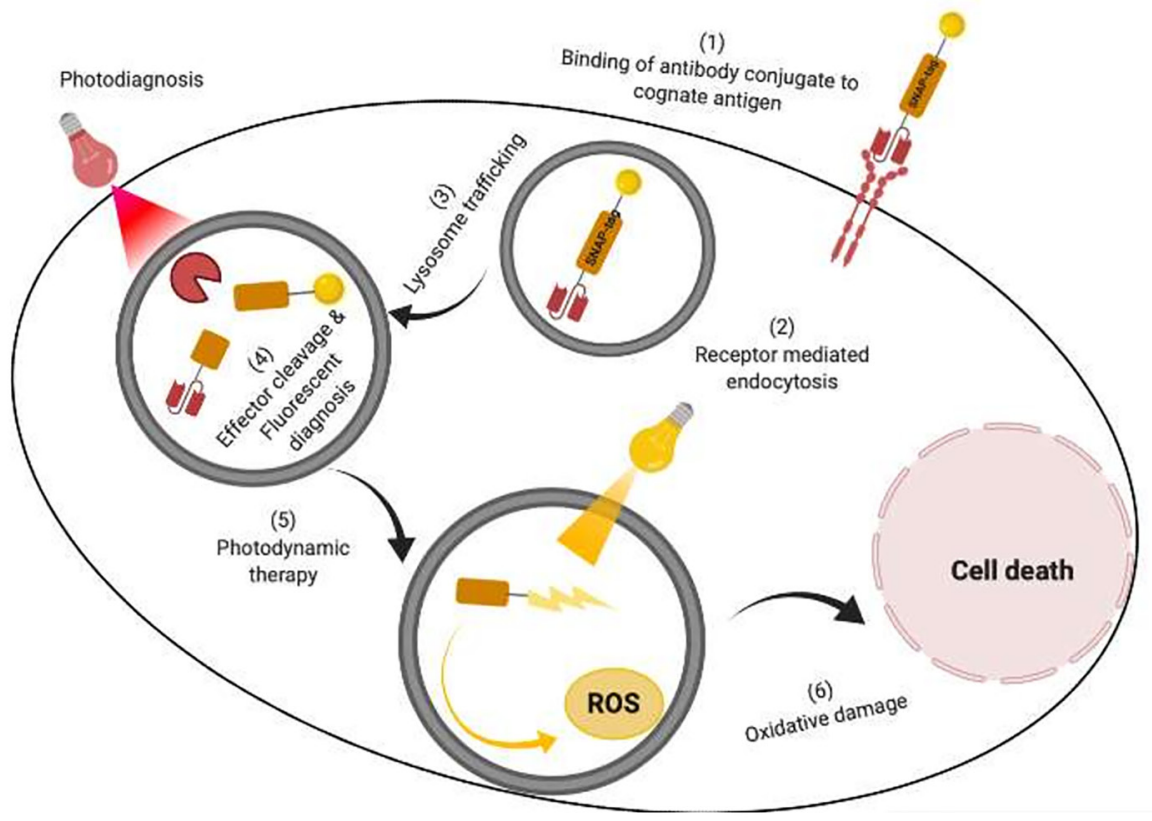

Figure 4: An illustration of targeted delivery of photoimmunotheranostic agent to specifically detect and kill cancer cells. (1) The SNAP-tag antibody photoimmunoconjugate first binds to the cognate receptor expressed on targeted cancer cells. (2 and $\mathbf{3}$ ). Thereafter the APC is internalized through receptor mediated endocytosis into the cell and trafficked to the lysosome. (4) The APC is subsequently exposed to a specific wavelength of light which enables fluorescent based detection of the targeted cell. (5) Irradiation of the APC with a different therapeutic wavelength in the presence of molecular oxygen causes reactive oxygen species (ROS) production which oxidatively damage the cell and induce cell death. 
Table 1: Cytotoxic activity of EGFR-specific recombinant antibody-drug conjugates

\begin{tabular}{|c|c|c|c|c|}
\hline EGFR-specific immunotherapy & Construct name & Disease model & $\mathrm{IC}_{50}$ value & References \\
\hline \multirow{7}{*}{ Recombinant Antibody-Drug Conjugates } & 425(scFv)-SNAP-AURIF & Epidermoid carcinoma & $8 \mathrm{nM}$ & {$[107,149]$} \\
\hline & & Triple-negative breast cancer & $2.6 \mathrm{nM}-4 \mathrm{nM}$ & \\
\hline & & Rhabdomyosarcoma & $8 \mathrm{nM}$ & \\
\hline & 1711(scFv)-SNAP-AURIF & Epidermoid carcinoma & $12 \mathrm{nM}$ & [107] \\
\hline & & Triple-negative breast cancer & $4 \mathrm{nM}$ & \\
\hline & & Rhabdomyosarcoma & $4 \mathrm{nM}$ & \\
\hline & $\alpha H E R 2(s c F v)-S N A P-A U R I F$ & Breast cancer & $0.6 \mathrm{nM}$ & [149] \\
\hline
\end{tabular}

scale protein production at high purity and quality [164, 165]. As stated by Chandramohan et al. (2013), the therapeutic success of a tumor-targeting agent is dependent on 2 critical factors: (1) efficient delivery to the tumor site at adequate concentration; and (2) uniform distribution throughout the neoplastic lesion [166]. ITs satisfy these criteria through their ability to bind with high specificity to surface antigens, causing their internalization and killing of the tumor cell by catalytic inhibition of protein synthesis within the cell cytosol [167]. Early developers of ITs were able to harness the activity of various plant and bacterial toxins. Toxins such as diphtheria toxin (DT), ricin A or Pseudomonas exotoxin A (also known as ETA or PE) are endowed with their own translocation domains and other components that can facilitate endosomal escape - a major rate-limiting step in the delivery of therapeutic macromolecules to the cytoplasm of cells [164]. With this peculiar characteristic, such toxins display higher toxicity than chemical agents; a single toxin molecule is enough to kill a cell while 10000 to 100000 molecules of toxic chemicals are required to produce the same effect [168-171].

In comparison to mAbs and ADCs, recombinant ITs display improved tumor penetration capability and greater anti-tumor efficacy in preclinical cancer models [172]. Furthermore, their unique features, including high specificity, extraordinary potency and lack of drug resistance, provided a rationale for the development of various EGFR-targeting ITs [173]. In order to target tumor cells via a surface molecule such as EGFR, the anti-tumor fusion toxin must: (1) recognize and bind with high affinity; (2) exhibit high selectivity for EGFRoverexpressing tumor cells to minimize unwanted sideeffects against normal tissues eventually expressing low levels of target antigen; and (3) have a catalytically active cytotoxic domain effectively inducing apoptosis at low concentrations [173]. Therefore, to achieve these requirements, EGFR has been under rigorous scrutiny, resulting in the generation of novel anti-EGFR ITs based on different growth factors, mAb templates and plant/ bacterial toxins. Some examples include anti-EGFR (scFv)-rGel (anti-EGFR single-chain antibody fragmentGelonin), $\mathrm{DAB}_{389} \mathrm{EGF}$ (DT toxin-EGF fusion protein), Sap3-EGF (Saponin toxin-EGF fusion protein), anti-

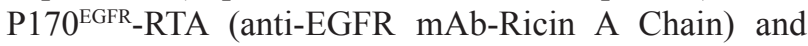

TGF $\alpha-\mathrm{PE}_{40}$ (Transforming Growth Factor type alpha-PE toxin with domain I deleted) [174]. While these toxins and growth factors have shown promising activity for a number of EGFR-driven malignancies, recombinant $\mathrm{Fv}$ variants conjugated to $\mathrm{PE}$ (or deimmunized $\mathrm{PE}$ variants), have been most commonly used to enhance cytotoxic activity, reduce immunogenicity, improve penetration into solid tumors and reduce the clearance time through the kidneys and liver [175-179].

Indeed, PE is a widely studied bacterial toxin consisting of a 613-residue, arranged in 3 separate regions: domain I is responsible for cell recognition (domain Ia as the cell-binding domain and domain $\mathrm{Ib}$ of unknown function), domain II for translocation into the cytosol and lastly, domain III which irreversibly inhibits protein synthesis by adenosine diphosphate (ADP)-ribosylation of human elongation factor 2 (EF-2) [172, 174, 180]. For recombinant IT development, researchers replaced the original cell-binding domain of PE by specific ligands or scFvs to allow specific targeting of tumor cells and efficient cell killing activity following internalization [163, 181, 182]. Moreover, various forms of PE (including PE40, PE38 and PE25) have been investigated to obviate impediments resulting from the immunogenicity of the toxin moiety [183]. More explicitly, PE40 (40 $\mathrm{kDa}$ ) was generated by the elimination of domain Ia and PE38, by the removal of a large part of domain $\mathrm{Ib}$, without compromising the cytotoxicity and ADPribosylation activity [172]. Similarly, to further reduce the immunogenicity and side-effects encountered with PE38, the smallest version of PE was engineered (known as PE24), which lacks domain II of PE, with exception of a 11 amino acid length furin cleavage site $[163,184]$ and which might show differences in cytotoxicity dependent on intracellular routing. The furin cleavage site plays a critical role in the intracellular processing of the toxin [185]. Additionally, the natural C-terminus REDLK sequence of PE was modified to KDEL to increase intracellular retention and cell-killing activity $[186,187]$.

Strategies based on anti-EGFR recombinant ITs bearing PE variants as lethal warheads, have thus shown promising results in several studies [184] (Table 3). Because of EGFR's role in the malignant process, elevated expression and accessibility on the tumor cell surface [163, 167, 174, 182, 188-190], EGFR-specific ITs 
Table 2: Cytotoxic activity of EGFR-specific antibody photoconjugates

\begin{tabular}{|c|c|c|c|c|}
\hline $\begin{array}{l}\text { EGFR-specific } \\
\text { immunotherapy }\end{array}$ & Construct name & Disease model & $\mathrm{IC}_{50}$ value & References \\
\hline \multirow{9}{*}{ Antibody photoconjugates } & scFv-425-SNAP-IR700 & Epidermoid carcinoma & $32 \mathrm{nM}$ & [89] \\
\hline & scFv-425-SNAP-IR700 & Melanoma skin cancer & 45 and $55 \mathrm{nM}$ & [89] \\
\hline & scFv-425-SNAP-IR700 & Triple-negative breast cancer & $26-69 \mathrm{nM}$ & [88] \\
\hline & scFv-45-SNAP-IR700 & Isolated ascites & $40-90 \mathrm{nM}$ & [39] \\
\hline & & Ovarian cancer & $45-66 \mathrm{nM}$ & [39] \\
\hline & Panitumumab-IR700 & Breast cancer & $67.57 \mathrm{nM}^{*}$ & {$[156]$} \\
\hline & Pertuzumab-IR700 & Breast \& gastric cancer & $67.57 \mathrm{nM}^{*}$ & [154] \\
\hline & Trastuzumab-IR700 & Breast \& gastric cancer & $67.57 \mathrm{nM}^{*}$ & {$[154,157,158,160]$} \\
\hline & Z-EGFR03115-IR700DX & Glioblastoma cancer & $0.5-0.1 \mu \mathrm{M}$ & {$[155]$} \\
\hline
\end{tabular}

"Molar $\mathrm{IC}_{50}$ values calculated from the molecular weight of the fusion protein and the reported $\mathrm{IC}_{50}$ values $(\mathrm{g} / \mathrm{ml})$.

represent highly potent immunotherapeutic agents across a wide range of diseases, including glioblastoma, breast, prostate and pancreatic cancer. Most strikingly, Niesen et al. (2015), have described the engineering and functional characterization of 2 novel recombinant ITs (scFv1711ETA' and scFv2112-ETA') based on panitumumab and cetuximab [174]. These ITs showed significant proapoptotic and anti-proliferative effects towards target cells, with $\mathrm{IC}_{50}$ values ranging from 4 to 460 picomolar (pM), depending on the EGFR expression level (Table 3) [188]. In comparison, the $\mathrm{IC}_{50}$ values of the internal reference $425(\mathrm{scFv})$-ETA' were similar or slightly better than the new ITs, with lower $\mathrm{IC}_{50}$ values observed against cell lines expressing the highest level of EGFR [188]. These results were in line with a previous report demonstrating a clear correlation between EGFR expression and the EGFR-specific IT [182, 188, 189]. In addition to the level of target receptor, other cell-type specific factors such as the rate of receptor turnover could strongly influence IT sensitivity [191].

Researchers have found that the overexpression of EGFR, is often accompanied by an increased production of the EGF receptor ligand TGF- $\alpha$, which results in receptor activation by autocrine stimulation and ultimately fosters malignant transformation [192]. In contrast to the EGFR-specific ITs, mAbs do not have the ability to kill tumor cells directly, but instead, they inhibit ligand binding, block signal transduction and inhibit EGFR gene expression [193, 194]. Schmidt et al. were interested in developing the EGFR-directed ITs, scFv (225)-ETA and scFv (14E1)-ETA, which (like their parental mAb) are able to competitively inhibit the binding of EGF and TGF $-\alpha$ to the EGF receptor, thereby blocking receptor activation [195].

Nonetheless, despite their high potency and affectivity, recombinant ITs face several disadvantages which limit their overall anti-tumor efficacy in clinical applications. The repeated use of high concentrations of these toxins gave rise to side-effects such as liver injury and vascular leak syndrome [174]. Moreover, some of the current ITs have low binding affinity with EGFR due to their monovalency and their effectiveness is further hindered by the cross-reactivity with EGFR on normal tissues [196, 197]. To address this problem, Meng and colleagues proposed the use of a bivalent recombinant anti-EGFR IT (DT390-BiscFv806) which showed promising activity against various cancers [173]. While several PE-based ITs have demonstrated potential in clinical and preclinical studies [173], the non-human effector component provoked an immune response, which leads to dose limitations.

To this end, various humanization approaches have been proposed: treating patients with immunosuppressive drugs, chemically modifying proteins via PEGylation [198-200], removal of human B-cell and T-cell epitopes from plant/bacterial toxins by site directed mutagenesis [201], or substituting bacterial/plant toxin moieties with toxins of human origin (to give rise to fully human cytolytic fusion proteins or hCFPs) [202, 203].

\section{Reducing immunogenicity: immune modulating drugs and the de-immunization of Pseudomonas Exotoxin A}

The therapeutic efficacy of recombinant ITs in clinical trials is considerably hampered by the formation of neutralizing antibodies $[32,188]$. This phenomenon often results in immune-related adverse events (such as allergic skin reactions and anaphylaxis) which further jeopardize the possibility of favourable treatment outcomes [204]. Therefore, several strategies have been put forward to mitigate the impact of immunogenicity on the therapeutic success of these agents. For instance, ITs are being used in combination with immune modulating drugs; in year 2004, 5 patients were pre-treated with rituximab to eliminate their B cells prior to LMB-1 (a mAb targeting Lewis Y-related B3 epitope with PE38) administration. However, all patients developed neutralizing antibodies by day 21 of drug administration, indicating that the elimination of $\mathrm{B}$ cells is not adequate to counteract an immune response 
Table 3: Cytotoxic activity of EGFR-specific immunotoxins and human cytolytic fusion proteins

\begin{tabular}{|c|c|c|c|c|}
\hline EGFR-specific immunotherapy & Construct name & Disease model & $\mathrm{IC}_{50}$ value & References \\
\hline & D2C7-(scdsFv)-PE38KDEL & Glioblastoma & $2.9-40.32 \mathrm{pM}^{*}$ & {$[167]$} \\
\hline & scFv (225)-ETA & Squamous cell carcinoma & $<14.29-271.43 \mathrm{pM}^{*}$ & {$[174,190]$} \\
\hline & scFv (14E1)-ETA & Squamous cell carcinoma & $27.97-111.89 \mathrm{pM}^{*}$ & {$[174,190]$} \\
\hline & 425(scFv)-ETA' & Squamous cell carcinoma & $2 \mathrm{pM}$ & {$[182,188,189]$} \\
\hline & & Breast cancer & $4 \mathrm{pM}$ & \\
\hline & & Prostate cancer & $35 \mathrm{pM}$ & \\
\hline & & Pancreatic cancer & $80 \mathrm{pM}$ & \\
\hline & & Rhabdomyosarcoma & $598 \mathrm{pM}$ & \\
\hline \multirow[t]{13}{*}{ Recombinant Immunotoxins } & $\begin{array}{l}\text { Humanized anti-EGFR } \\
\text { (huscFv)-PE25KDEL }\end{array}$ & Epidermoid carcinoma & $9.43 \mathrm{nM}^{*}$ & [163] \\
\hline & scFv1711-ETA' & Squamous cell carcinoma & $18 \mathrm{pM}$ & [188] \\
\hline & & Breast cancer & $32 \mathrm{pM}$ & \\
\hline & & Prostate cancer & $192 \mathrm{pM}$ & \\
\hline & & Pancreatic cancer & $260 \mathrm{pM}$ & \\
\hline & & Rhabdomyosarcoma & $240 \mathrm{pM}$ & \\
\hline & scFv2112-ETA' & Squamous cell carcinoma & $4 \mathrm{pM}$ & [188] \\
\hline & & Breast cancer & $11 \mathrm{pM}$ & \\
\hline & & Prostate cancer & $55 \mathrm{pM}$ & \\
\hline & & Pancreatic cancer & $290 \mathrm{pM}$ & \\
\hline & & Rhabdomyosarcoma & $460 \mathrm{pM}$ & \\
\hline & $\alpha$ EGFR (scFv)-MAP tau & Pancreatic carcinoma & $1000 \mathrm{nM}$ & [211] \\
\hline & & Prostate cancer & $2500-2800 \mathrm{nM}$ & \\
\hline \multirow[t]{3}{*}{ Human Cytolytic Fusion Proteins } & scFv1711-GrBR201K & Epidermoid carcinoma & $133.3 \mathrm{nM}$ & [35] \\
\hline & & Rhabdomyosarcoma & $21.2 \mathrm{nM}$ & \\
\hline & aEGFR (scFv)-Angiogenin & Epidermoid carcinoma & $12.5-45 \mathrm{nM}$ & [212] \\
\hline
\end{tabular}

"Molar $\mathrm{IC}_{50}$ values calculated from the molecular weight of the fusion protein and the reported $\mathrm{IC}_{50}$ values $(\mathrm{g} / \mathrm{ml})$.

$[200,205]$. To this end, Pentostatin was used to abrogate the activity of T-cells, along with Cytoxan (to eliminate B cells) in the treatment of mesothelioma patients with SS1P (an anti-mesothelin PE-based IT) [206]. Furthermore, with substantial progress in protein deimmunization by the Pastan group, the first "de-immunized" PE-based mesothelin-targeting IT was engineered, most commonly known as LMB-100, consisting of a humanized Fab fused to LO10 (PE toxin with 7 major B cell epitopes silenced) [191]. While T-cell de-immunization efforts have not yet been assessed in the clinical setting, the $\mathrm{B}$ cell de-immunized IT, LMB-100 has recently been tested in 2 clinical trials. From the results generated (https:// clinicaltrials.gov/: NCT03436732, NCT03644550), it was concluded that while using a humanized antibody and the silencing of B-cell epitopes is promising, it is not sufficient to completely abolish an immune response against recombinant ITs. Consequently, the arguments above warrant the need to intensify research for alternative strategies to alleviate the impacts of immunogenicity. This would also be a salient point to consider in the development of next-generation EGFR-specific recombinant ITs.

\section{HUMAN CYTOLYTIC FUSION PROTEINS TARGETING EGFR}

The 4th generation of ITs, also known as targeted human cytolytic fusion proteins (hCFPs) represent a combination of fully human sequences for the antibody, as well as the cytotoxic module [207]. To this end, a portfolio of very potent endogenous proteins of human origin have been identified as potent candidates for the production of less or non-immunogenic ITs. These include granzyme B (GrB), immunoRNAses (such as Angiogenin [Ang]), death-associated protein kinase and the microtubuleassociated protein tau (MAP tau), amongst others [32, 33, $172,208]$. For the selective elimination of tumor cells via apoptosis, hCFPs must be able to bind to the target antigen and be effectively internalized, followed by endosomal escape and release of the cytotoxic cargo into the cytosol of the cell. The higher $\mathrm{IC}_{50}$ values observed with hCFPs as compared to PE-based ITs (Table 3), reveal that there is a need for translocation promoting structures in the natural human enzymes. In order to improve the cytotoxic activity, endosomolytic compounds, such as chloroquine 
or wortmannin, could be used [32, 209]. Nonetheless, recent studies point to the use of adapter sequences that facilitate vesicular escape of the effector molecule into the cytosol of the tumor cell $[32,210]$. Here, we review the past and current research conducted in the context of EGFR-targeted hCFPs bearing GrB, Ang, or MAP tau [32, $33,210,211]$.

\section{Granzyme B}

Granzyme B (GrB) is a cytolytic serine protease found in granules of innate immune effector cells (natural killer and cytotoxic T-lymphocyte cells), which functions to protect the body against viral infections and malignant cells [35, 211-214]. Due to its cytotoxic nature, GrB exists as a zymogen with an $\mathrm{N}$-terminal signal sequence which can be processed in the endoplasmic reticulum and post-translationally modified with mannose-6-phosphate, priming it for packaging with serglycin and perforin complex into secretory vesicles [31]. During cytolytic destruction of targeted cells by cytotoxic T-lymphocytes (CTLs), cytotoxic granules are released at the intercellular spaces called immunological synapses [32, 215]. Thereafter, perforin is released to polymerize and create transmembrane pores on targeted cell membrane, to ease GrB access to molecular cytosolic targets [204]. Alternatively, GrB can enter targeted cell cytosol through the endosomolytic perforin activity, following mannose-6phosphate receptor mediated endocytosis [216, 217]. Once in the cytosol, GrB can catalytically cleave and produce truncated versions of pro-apoptotic proteins of the BcL2 family such as BH3 interacting domain death agonist (BID), which eventually translocates to the mitochondria, causing cytochrome $\mathrm{c}$ release and activating downstream apoptotic signals inducing DNA damage, hence cell death [33]. The human origin of GrB makes it an ideal candidate as an effector molecule for the generation of recombinant hCFPs capable of circumventing the adverse effects (e.g., immunogenicity and side effects) usually associated with plant and bacterial toxins $[32,33]$. In this regard, Liu et al. (2003), developed a GrB which was genetically fused to a single chain anti-melanoma antibody fragment (antigp240) that could specifically induce apoptosis in targeted cells 8 hours post-treatment with $\mathrm{IC}_{50}$ values of $20 \mathrm{nM}$ [32, 36, 217, 218]. Corroborating results from Dälken et al. and Oberoi et al. supported the specificity and therapeutic efficacy of TGF $\alpha$-GrB hCFPs in killing EGFR overexpressing cancer cells using pico to nanomolar $\mathrm{IC}_{50}$ concentrations in the presence of endosomolytic chloroquine reagent [217, 219]. However, GrB hCFP targeted therapy is usually impaired by the presence of the endogenous inhibitor serine protease serpin B9, naturally protecting CTLs from granules-loaded GrB [36, 215]. To exert its inhibitory effect, serpin B9 irreversibly binds to $\mathrm{GrB}$ in a $1: 1$ stoichiometry which is stabilized by various chemical interactions including hydrogen and hydrophobic bonds [36, 220]. Using computational modelling and recombinant antibody technology, both Niesen and Amoury et al. (2016) developed an inhibitory resistant version of GrB $(201 \mathrm{~K})$, genetically fused either to panitumumab (scFv1711) or EpCAM scFv fragment $[35,221]$. This new GrB version (Gb201K- $\alpha$ EpCAM) could kill $\alpha$ EpCAM overexpressing tumor cells using nanomolar $\mathrm{IC}_{50}$ concentrations which were three fold lower than conventional IT conjugates $(\alpha$ EpCAM $(\mathrm{scFv})$ ETA counterparts) [34, 200]. Besides this, Gb201K$\alpha$ EpCAM did not cause any side effects, which offers better therapeutic tolerability, allowing repeated treatment schedules with higher doses, which are normally limited in highly immunogenic bacterial ITs treatment as a result of antibody-neutralizing immune responses [35, 213].

\section{Angiogenin}

Angiogenin (Ang) or ribonuclease 5 (RNase5), is a $14 \mathrm{kDa}$ stress-activated enzyme belonging to the pancreatic ribonuclease (RNase) superfamily, which possesses angiogenic and ribonucleolytic activities [213, 222]. Using its nuclear ribonuclease activity, Ang has shown to primarily function to regulate angiogenesis and positively influence the activation of molecular pathways driving cancer's metastatic, invasive and migratory potential $[33,36,211]$. Also, Ang has shown the ability to translocate in the cell cytosol in response to oxidative stress and induce apoptosis by abolishing protein synthesis through tRNA, 5S, 18S, and 28S rRNA hydrolysis [34, 36, 223, 224]. Unfortunately, Ang therapeutic efficacy has been hampered by the antagonistic effect of the endogenous human placental ribonuclease inhibitor 1 (RNH1), which acts to prevent self-tissue damage [34, $212,225,226]$. To bypass this obstacle, Cremer et al. (2015) and Gresch et al. (2018), engineered multiple Ang mutant versions, which have decreased affinity for their RNH1 [34, 223]. According to these studies, the Ang mutants were associated with increased cytotoxicity towards CD64 (activated macrophages) and CD89 positive cells (acute myeloid leukaemia) compared with their wild-type and the gold standard ETA'-hCFP, respectively [34, 223, 227]. Their targeted cytotoxic effects were corroborated by Yoon et al. (1999) which specifically killed EGFR-expressing cells using EGFR-Ang fusion proteins using $\mathrm{IC}_{50}$ concentrations of 12.5-45 nM [223, 227].

\section{Microtubule-associated protein tau}

Microtubules are critical structures in the process of cell division; they allow the alignment of chromosomes along the metaphase plate, before chromatids are pulled towards opposite poles during anaphase [212]. This process is tightly regulated through an evolutionary conserved checkpoint known as the spindle assembly checkpoint 
(SAC) [228]. Anti-mitotic drugs, most specifically the microtubule-targeting agents (MTAs), disturb normal spindle formation, activating SAC, resulting in cell cycle arrest, and cell death [229]. However, despite their potency and versatile application in oncology, MTAs lack specificity towards cancer cells and their repeated usage gives rise to the phenomenon of drug resistance [32, 230]. In view of addressing these challenges, a human anti-mitotic protein (known as MAP tau) was identified, showing similar activities as MTAs and allowing the development of potential hCFPs [231-234].

MAP tau belongs to a family of proteins (the microtubule-associated proteins), which regulate the stability of microtubules [211, 234, 235]. More explicitly, MAP tau binds to tubulin in a longitudinal fashion, causing the bridging of tubulin interfaces and hampering the shrinking phase of microtubule dynamics [32]. Given this indispensable role, the first MAP tau-based hCFP was thus engineered, consisting of an anti-EGFR scFv genetically fused to MAP tau isoform 3 [211]. To exclude the risk of neurodegenerative disorders, MAP tau-based hCFPs were deliberately designed with the vital phosphorylation sites of tau (S156 and S204) removed [211]. Moreover, the highly selective nature of the antibody fragment limits permeability through the blood-brain barrier and avoids the accumulation of MAP tau in the brain [211, 236].

Anti-EGFR (scFv)-MAP tau demonstrates specific cytotoxicity towards cells that express its target receptor, and no activity towards EGFR-negative HEK293 cells $[32,211]$. However, the efficacy of this effector protein is highly dependent on cell proliferation, making rapidly dividing cancer cells as the target of choice for MAP taubased hCFPs [211]. Moreover, this fusion protein showed increased tolerance in xenograft mice tumor models as compared to the PE-based control [211, 234, 237]. Like recombinant ITs, hCFPs avoid the need for complex chemistry processes and can be produced in large quantities in a one-step fermentation process [211]. Nonetheless, despite their potential clinical value, ease of manufacture and suitability for the development of patient-tailored therapies, their escape mechanism from the endosomes to the cytosol remains unclear [234, 237, 238]. Further investigation is therefore needed to enhance the preclinical therapeutic efficacy of these anti-cancer agents.

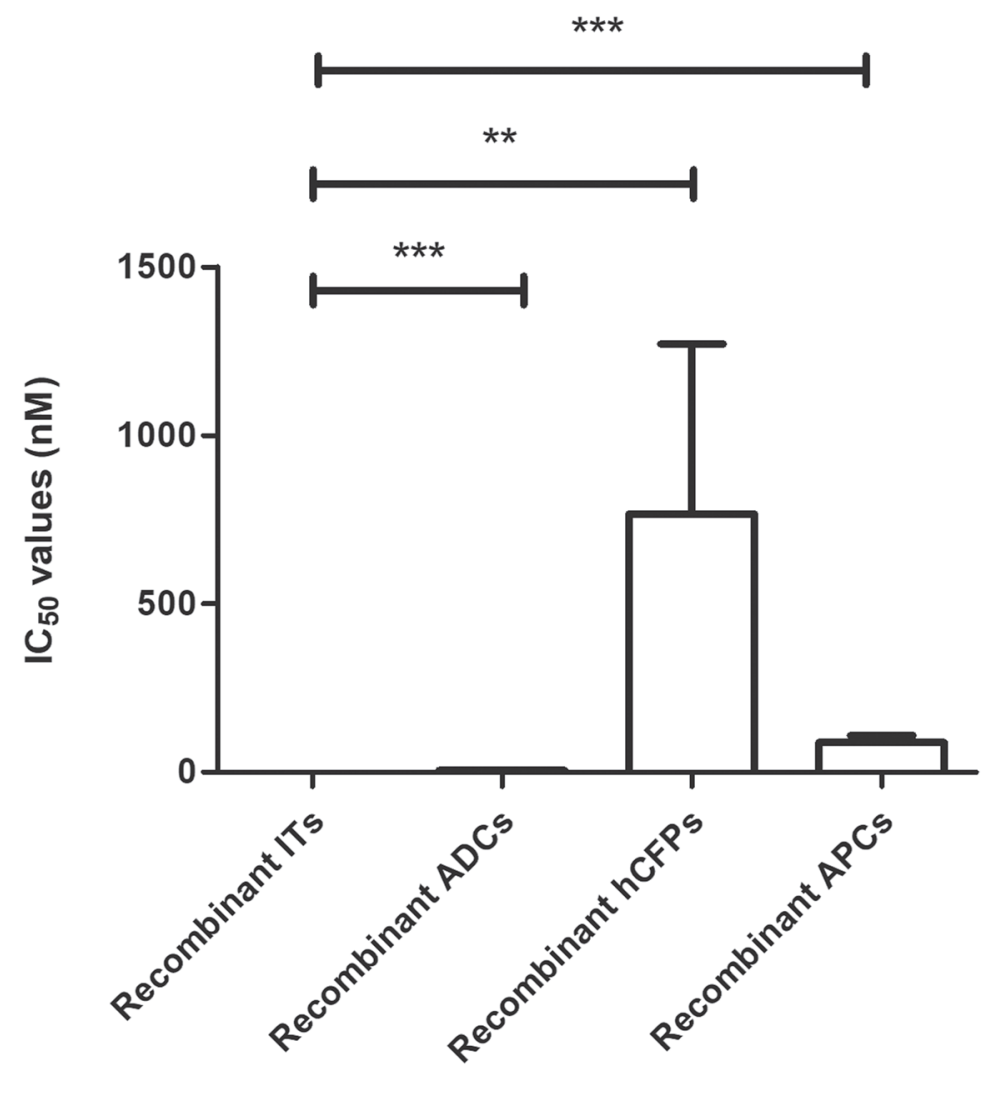

Type of armed antibodies

Figure 5: Comparative analysis of the efficacy of immunoconjugates currently in development. Based on publicly sourced $\mathrm{IC}_{50}$ values, recombinant ITs are highly cytotoxic agents. Student's $t$-tests were performed to determine statistical differences $(p<0.05)$ between recombinant ITs and the other classes of therapeutics. Results reinforced the fact that recombinant ITs display higher cytotoxicities than recombinant ADCs $(p<0.0001)$, recombinant hCFPs $(p<0.005)$ or recombinant APCs $(p<0.001)$. 


\section{CONCLUSIONS \\ AND \\ FUTURE DIRECTIONS}

Cancer treatment has been revolutionized by antibody-based therapies that allow for specific targeting of diseased cells. However, the early promise of naked mAbs was hampered by the low success rates (15\%) from Phase I to FDA approval [234]. The advent of genetic engineering ensured the evolution of therapeutic mAbs to yield molecules with reduced immunogenicity, increased half-life and enhanced ability to recruit immune effector responses. Among these, warhead-armed mAbs, are improved, highly potent cytotoxic compounds albeit, with a limited number currently approved for clinical useattributed to insufficient, detailed knowledge on strategies on how to best deliver different payloads to their target intracellular compartments [239]. This is evident with EGFR-specific passive immunotherapeutics, whereby a preclinical comparison of the calculated average $\mathrm{IC}_{50}$ values \pm standard deviations of the constructs described in the tables of this review are as follows: $0.133 \pm 0.039$ $\mathrm{nM}$ (recombinant ITs), $5.700 \pm 1.446 \mathrm{nM}$ (recombinant ADCs), $88.48 \pm 21.13 \mathrm{nM}$ (recombinant APCs), $766.7 \pm$ $505.1 \mathrm{nM}$ (recombinant hCFPs). These relative cytotoxic differences for the total number of constructs analyzed is more or less reflected for the Panitumumab-derived constructs showing the same principle results, while confirming the following efficiencies in selective cell killing; $\mathrm{rIT}>\mathrm{rADCs}>\mathrm{rAPC}>\operatorname{rhCFP}$ (Figure 5).

Several decades of research ascribes this to differences in efficient delivery of the different types of warheads: for example, PE possesses functional domains which facilitate retrograde transport from the Golgi to the endoplasmic reticulum and improve translocation into the cytosol, while avoiding lysosomal degradation [240]. Furthermore, the catalytic capability of the warhead is another important factor, whereby the numbers of molecules needed to induce apoptosis, influences efficacy, favoring payloads where only a few molecules reach their target compartments yet induce efficient cell killing [241]. Thus, the next generation of immunoconjugates will necessitate alterations to the antibody and/or the cytotoxic moieties and will likely be dependent on target receptor densities, valency of the constructs, efficiency of receptor mediated uptake and subcellular delivery of warheads to their compartment of action. To this end, some progress has ensued, with the engineering of bispecific antibodies and protein translocation domains flanked with cleavable adapters to allow efficient internalization and transport of lethal warheads into the cytosol, respectively [242]. Additionally, the introduction of supercomputing tools to study enzyme-substrate interactions $[33,159]$, and modelling simulations that measure cellular processing parameters including binding, internalization, trafficking, and drug release/accumulation will undoubtedly foster the development of next-generation highly efficient apoptosis-inducing molecules [32]. The future curative potential of immunoconjugates will rely on emerging multimodality combinatorial approaches that explore nonoverlapping mechanisms of action and toxicity profiles, resulting in synergistic efficacy. Continued optimization of antibody-mediated therapeutics and the evolving era of personalized treatment ensures a diversified immunotherapy armamentarium to combat cancer and improve patient outcomes.

\section{Author contributions}

F.A.N.B., N.M., and S.B. conceived and designed the paper. F.A.N.B., N.M., N.E.T.C., J.D.N., J.E.N., and G.V. wrote the initial draft of the manuscript. F.A.N.B. and N.M. collected the data for Tables 1-3. N.M. analysed and interpreted the data for Figure 5. F.A.N.B, N.M., E.P., K.N., and S.B. contributed to the editing and revision of the manuscript. All authors read and approved the final version of the manuscript.

\section{CONFLICTS OF INTEREST}

The authors declare no conflicts of interest. Prof Barth is inventor on several patent applications describing EGFR specific PDT and hCFP. Most of these patents have been assigned to UCT.

\section{FUNDING}

This work is based on the research supported in part by the National Research Foundation of South Africa (Grant Number 47904).

\section{REFERENCES}

1. Li H, Yu C, Jiang J, Huang C, Yao X, Xu Q, Yu F, Lou L, Fang J. An anti-HER2 antibody conjugated with monomethyl auristatin $\mathrm{E}$ is highly effective in HER2positive human gastric cancer. Cancer Biol Ther. 2016; 17:346-354. https://doi.org/10.1080/15384047.2016.1139 248. [PubMed]

2. Weng MS, Chang JH, Hung WY, Yang YC, Chien MH. The interplay of reactive oxygen species and the epidermal growth factor receptor in tumor progression and drug resistance. J Exp Clin Cancer Res. J Exp Clin Cancer Res. 2018; 37:61. https://doi.org/10.1186/s13046-018-0728-0. [PubMed]

3. Dawson JP, Berger MB, Lin C, Schlessinger J, Lemmon MA, Kathryn M, Ferguson KM. Epidermal Growth Factor Receptor Dimerization and Activation Require Ligand-Induced Conformational Changes in the Dimer Interface Epidermal Growth Factor Receptor Dimerization and Activation Require Ligand-Induced Conformational Changes in the Dimer Inter. Mol Cell Biol. 2005; 25:7734-7742. https://doi.org/10.1128/ MCB.25.17.7734-7742.2005. [PubMed] 
4. Herbst RS. Review of epidermal growth factor receptor biology. Int J Radiat Oncol Biol Phys. 2004; 59:21-26. https://doi.org/10.1016/j.ijrobp.2003.11.041. [PubMed]

5. Jorissen RN, Walker F, Pouliot N, Garrett TPJ, Ward $\mathrm{CW}$, Burgess AW. Epidermal growth factor receptor: Mechanisms of activation and signalling. Exp Cell Res. 2003; 284:31-53. https://doi.org/10.1016/S00144827(02)00098-8. [PubMed]

6. Li Z, Wang M, Yao X, Luo W, Qu Y, Yu D, Li X, Fang J, Huang C. Development of a Novel EGFR-Targeting Antibody-Drug Conjugate for Pancreatic Cancer Therapy. Target Oncol. Target Oncol. 2019; 14:93-105. https://doi. org/10.1007/s11523-018-0616-8. [PubMed]

7. Paluncic J, Kovacevic Z, Jansson PJ, Kalinowski D, Merlot AM, Huang MLH, Lok HC, Sahni S, Lane DJR, Richardson DR. Roads to melanoma: Key pathways and emerging players in melanoma progression and oncogenic signaling. Biochim Biophys Acta. 2016; 1863:770-784. https://doi. org/10.1016/j.bbamcr.2016.01.025. [PubMed]

8. Herbst RS, Langer CJ. Epidermal Growth Factor Receptors as a Target for Cancer Treatment: The Emerging Role of IMC-C225 in the Treatment of Lung and Head and Neck Cancers. Semin Oncol. 2002; 29:27-36. https://doi. org/10.1053/sonc.2002.31525. [PubMed]

9. Kobayashi H, Griffiths GL, Choyke PL. Near-Infrared Photoimmunotherapy: Photoactivatable Antibody-Drug Conjugates (ADCs). Bioconjug Chem. American Chemical Society. 2020; 31:28-36. https://doi.org/10.1021/acs. bioconjchem.9b00546. [PubMed]

10. Bracher A, Cardona AS, Tauber S, Fink AM, Steiner A, Pehamberger H, Niederleithner H, Petzelbauer P, Gröger M, Loewe R. Epidermal Growth Factor Facilitates Melanoma Lymph Node Metastasis by Influencing Tumor Lymphangiogenesis. J Invest Dermatol. 2013; 133:230 238. https://doi.org/10.1038/jid.2012.272. [PubMed]

11. Ogata F, Nagaya T, Nakamura Y, Sato K, Okuyama S, Maruoka Y, Choyke PL, Kobayashi H. Near-infrared photoimmunotherapy: a comparison of light dosing schedules. Oncotarget. 2017; 8:35069-35075. https://doi. org/10.18632/oncotarget.17047. [PubMed]

12. Sato K, Watanabe R, Hanaoka H, Harada T, Nakajima T, Kim I, Paik CH, Choyke PL, Kobayashi H. Photoimmunotherapy: Comparative effectiveness of two monoclonal antibodies targeting the epidermal growth factor receptor. Mol Oncol. 2014; 8:620-632. https://doi.org/10.1016/j. molonc.2014.01.006. [PubMed]

13. Moran T, Sequist LV. Timing of epidermal growth factor receptor tyrosine kinase inhibitor therapy in patients with lung cancer with EGFR mutations. J Clin Oncol. 2012; 30:3330-3336. https://doi.org/10.1200/JCO.2012.43.1858. [PubMed]

14. Giusti RM, Shastri KA, Cohen MH, Keegan P, Pazdur R. FDA Drug Approval Summary: Panitumumab (Vectibix). Oncologist. 2007; 12:577-583. https://doi.org/10.1634/ theoncologist.12-5-577. [PubMed]
15. Pao W, Miller VA, Politi KA, Riely GJ, Somwar R, Zakowski MF, Kris MG, Varmus H. Acquired resistance of lung adenocarcinomas to gefitinib or erlotinib is associated with a second mutation in the EGFR kinase domain. PLoS Med. 2005; 2:e73. https://doi.org/10.1371/journal. pmed.0020073. [PubMed]

16. Yun $\mathrm{CH}$, Mengwasser KE, Toms AV, Woo MS, Greulich H, Wong KK, Meyerson M, Eck MJ. The T790M mutation in EGFR kinase causes drug resistance by increasing the affinity for ATP. Proc Natl Acad Sci U S A. 2008; 105:2070 2075. https://doi.org/10.1073/pnas.0709662105. [PubMed]

17. Zheng D, Hu M, Bai Y, Zhu X, Lu X, Wu C, Wang J, Liu L, Wang Z, Ni J, Yang Z, Xu J. EGFR G796D mutation mediates resistance to osimertinib. Oncotarget. 2017; 8:49671-49679. https://doi.org/10.18632/oncotarget.17913. [PubMed]

18. Planchard D, Loriot Y, André F, Gobert A, Auger N, Lacroix L, Soria JC. EGFR-independent mechanisms of acquired resistance to AZD9291 in EGFR T790M-positive NSCLC patients. Ann Oncol. 2015; 26:2073-8. https://doi. org/10.1093/annonc/mdv319. [PubMed]

19. Cunningham D, Humblet Y, Siena S, Khayat D, Bleiberg H, Santoro A, Bets D, Mueser M, Harstrick A, Verslype C, Chau I, Van Cutsem E. Cetuximab monotherapy and cetuximab plus irinotecan in irinotecan- refractory metastatic colorectal cancer. N Engl J Med. 2004; 351:337345. https://doi.org/10.1056/NEJMoa033025. [PubMed]

20. Roberts PJ, Der CJ. Targeting the Raf-MEK-ERK mitogenactivated protein kinase cascade for the treatment of cancer. Oncogene. 2007; 26:3291-3310. https://doi.org/10.1038/ sj.onc.1210422. [ubMed]

21. Kirkpatrick P, Graham J, Muhsin M. Cetuximab. Nat Rev Drug Discov. 2004; 3:549-50. https://doi.org/10.1038/ $\underline{\text { nrd1445. }}$ [PubMed]

22. Wu M, Rivkin A, Pham T. Panitumumab: human monoclonal antibody against epidermal growth factor receptors for the treatment of metastatic colorectal cancer. Clin Ther. 2008; 30:14-30. https://doi.org/10.1016/j. clinthera.2008.01.014. [PubMed]

23. Lu M, Wang X, Shen L, Jia J, Gong J, Li J, Li J, Li Y, Zhang X, Lu Z, Zhou J, Zhang X. Nimotuzumab plus paclitaxel and cisplatin as the first line treatment for advanced esophageal squamous cell cancer: A single centre prospective phase II trial. Cancer Sci. 2016; 107:486-490. https://doi.org/10.1111/cas.12894. [PubMed]

24. Vacchelli E, Aranda F, Eggermont A, Galon J, SautèsFridman C, Zitvogel L, Kroemer G, Galluzzi L. Trial Watch: Tumor-targeting monoclonal antibodies in cancer therapy. OncoImmunology. 2014; 3:e27048. https://doi. org/10.4161/onci.27048. [PubMed]

25. Tsironis G, Ziogas DC, Kyriazoglou A, Lykka M, Koutsoukos K, Bamias A, Dimopoulos MA. Breakthroughs in the treatment of advanced squamous-cell NSCLC: not the neglected sibling anymore? Ann Transl Med. 2018; 6:143. https://doi.org/10.21037/atm.2018.02.18. [PubMed] 
26. Concu R, Cordeiro MNDS. Cetuximab And The Head And Neck Squamous Cell. Curr Top Med Chem. 2018; 18:192-198. https:// doi.org/10.2174/1568026618666180112162412. [PubMed]

27. Weinstein JN, Van Osdol W. Early intervention in cancer using monoclonal antibodies and other biological ligands: Micropharmacology and the "binding site barrier.". Cancer Res. 1992; 52:2747s-2751s. [PubMed]

28. Waldmann H. Human Monoclonal Antibodies: The Benefits of Humanization. Methods Mol Biol. 2019; 1904:1-10. https://doi.org/10.1007/978-1-4939-8958-4_1. [PubMed]

29. Carter PJ, Senter PD. Antibody-Drug Conjugates for Cancer Therapy. Cancer J. 2008; 14:154-169. https://doi. org/10.1097/PPO.0b013e318172d704. [PubMed]

30. Vezina HE, Cotreau M, Han TH, Gupta M. Antibody-Drug Conjugates as Cancer Therapeutics: Past, Present, and Future. J Clin Pharmacol. 2017; 57:S11-S25. https://doi. org/10.1002/jcph.981. [PubMed]

31. Bakhtiar R. Antibody drug conjugates. Biotechnol Lett. 2016; 38:1655-1664. https://doi.org/10.1007/s10529-0162160-x. [PubMed]

32. Mungra N, Jordaan S, Hlongwane P, Naran K, Chetty $\mathrm{S}$, Barth S. Targeted human cytolytic fusion proteins at the cutting edge: Harnessing the apoptosis-inducing properties of human enzymes for the selective elimination of tumor cells. Oncotarget. 2019; 10:897-915. https://doi. org/10.18632/oncotarget.26618. [PubMed]

33. Hlongwane P, Mungra N, Madheswaran S, Akinrinmade OA, Chetty S, Barth S. Human Granzyme B Based Targeted Cytolytic Fusion Proteins. Biomedicines. 2018; 6:72. https://doi.org/10.3390/biomedicines6020072. [PubMed]

34. Cong X, Cremer C, Nachreiner T, Barth S, Carloni P. Engineered human angiogenin mutations in the placental ribonuclease inhibitor complex for anticancer therapy: Insights from enhanced sampling simulations. Protein Sci. 2016; 25:1451-1460. https://doi.org/10.1002/pro.2941. [PubMed]

35. Niesen J, Hehmann-Titt G, Woitok M, Fendel R, Barth S, Fischer R, Stein C. A novel fully-human cytolytic fusion protein based on granzyme B shows in vitro cytotoxicity and ex vivo binding to solid tumors overexpressing the epidermal growth factor receptor. Cancer Lett. 2016; 374:229-240. https://doi.org/10.1016/j.canlet.2016.02.020. [PubMed]

36. Bochicchio A, Jordaan S, Losasso V, Chetty S, Perera RC, Ippoliti E, Barth S, Carloni P. Designing the sniper: Improving targeted human cytolytic fusion proteins for anti-cancer therapy via molecular simulation. Biomedicines. 2017; 5:9. https://doi.org/10.3390/biomedicines5010009. [PubMed]

37. Jordaan S, Chetty S, Mungra N, Koopmans I, van Bommel PE, Helfrich W, Barth S. CSPG4: A target for selective delivery of human cytolytic fusion proteins and TRAIL. Biomedicines. 2017; 5:37. https://doi.org/10.3390/biomedicines5030037. [PubMed]
38. Maawy AA, Hiroshima Y, Zhang Y, Heim R, Makings L, Garcia-Guzman M, Luiken GA, Kobayashi H, Hoffman RM, Bouvet M. Near infra-red photoimmunotherapy with anti-CEA-IR700 results in extensive tumor lysis and a significant decrease in tumor burden in orthotopic mouse models of pancreatic cancer. PLoS One. 2015; 10:e0121989. https://doi.org/10.1371/journal.pone.0121989. [PubMed]

39. Bauerschlag D, Meinhold-Heerlein I, Maass N, Bleilevens A, Bräutigam K, Al Rawashdeh W, Di Fiore S, Haugg AM, Gremse F, Steitz J, Fischer R, Stickeler E, Barth $\mathrm{S}$, Hussain AF. Detection and Specific Elimination of EGFR+ Ovarian Cancer Cells Using a Near Infrared Photoimmunotheranostic Approach. Pharm Res. Pharm Res. 2017; 34:696-703. https://doi.org/10.1007/s11095017-2096-4. [PubMed]

40. Maawy AA, Hiroshima Y, Zhang Y, Garcia-Guzman M, Luiken GA, Kobayashi H, Hoffman RM, Bouvet M. Photoimmunotherapy lowers recurrence after pancreatic cancer surgery in orthotopic nude mouse models. J Surg Res. 2015; 197:5-11. https://doi.org/10.1016/j. jss.2015.02.037. [PubMed]

41. Nakajima T, Sano K, Choyke PL, Kobayashi H. Improving the efficacy of photoimmunotherapy (PIT) using a cocktail of antibody conjugates in a multiple antigen tumor model. Theranostics. 2013; 3:357-365. https://doi.org/10.7150/ thno.5908. [PubMed]

42. Nagaya $T$, Nakamura $\mathrm{Y}$, Okuyama $\mathrm{S}$, Ogata $\mathrm{F}$, Maruoka Y, Choyke PL, Kobayashi H. Near-Infrared Photoimmunotherapy Targeting Prostate Cancer with Prostate-Specific Membrane Antigen (PSMA) Antibody. Mol Cancer Res. 2017; 15:1153-1162. https://doi. org/10.1158/1541-7786.MCR-17-0164. [PubMed]

43. Wang M, Yin B, Wang HY, Wang RF. Current advances in T-cell-based cancer immunotherapy. Immunotherapy. 2014; 6:1265-1278. https://doi.org/10.2217/imt.14.86. [PubMed]

44. Ma S, Li X, Wang X, Cheng L, Li Z, Zhang C, Ye Z, Qian Q. Current progress in car-t cell therapy for solid tumors. Int J Biol Sci. 2019; 15:2548-2560. https://doi.org/10.7150/ ijbs.34213. [PubMed]

45. Gomes-Silva D, Ramos CA. Cancer immunotherapy using CAR-T cells: from the research bench to the assembly line. Biotechnol J. 2018; 13:10.1002/biot.201700097. https://doi. org/10.1002/biot.201700097. [PubMed]

46. Garg AD, Coulie PG, Van den Eynde BJ, Agostinis P. Integrating Next-Generation Dendritic Cell Vaccines into the Current Cancer Immunotherapy Landscape. Trends Immunol. 2017; 38:577-593. https://doi.org/10.1016/j. it.2017.05.006. [PubMed]

47. Ahmed MS, Bae YS. Dendritic cell-based therapeutic cancer vaccines: past, present and future. Clin Exp Vaccine Res. 2014; 3:113-116. https://doi.org/10.7774/ cevr.2014.3.2.113. [PubMed]

48. Anguille S, Smits EL, Bryant C, Van Acker HH, Goossens H, Lion E, Fromm PD, Hart DN, Van Tendeloo VF, Berneman ZN. Dendritic cells as pharmacological tools for 
cancer immunotherapys. Pharmacol Rev. 2015; 67:731753. https://doi.org/10.1124/pr.114.009456. [PubMed]

49. Stock S, Schmitt M, Sellner L. Optimizing Manufacturing Protocols of Chimeric Antigen Receptor $\mathrm{T}$ Cells for Improved Anticancer Immunotherapy. Int J Mol Sci. 2019; 20:6223. https://doi.org/10.3390/ijms20246223. [PubMed]

50. Bridgeman JS, Hawkins RE, Hombach AA, Abken H, Gilham DE. Building Better Chimeric Antigen Receptors for Adoptive T Cell Therapy. Curr Gene Ther. 2010; 10:77-90. https://doi.org/10.2174/156652310791111001. [PubMed]

51. Peters S, Kerr KM, Stahel R. PD-1 blockade in advanced NSCLC: A focus on pembrolizumab. Cancer Treat Rev. 2018; 62:39-49. https://doi.org/10.1016/j.ctrv.2017.10.002. [PubMed]

52. Ross JS, Gray K, Gray GS, Worland PJ, Rolfe M. Anticancer antibodies. Am J Clin Pathol. 2003; 119:472-485. https:// doi.org/10.1309/Y6LP-C0LR-726L-9DX9. [PubMed]

53. Clynes RA, Towers TL, Presta LG, Ravetch JV. Inhibitory Fc receptors modulate in vivo cytotoxicity against tumor targets. Nat Med. 2000; 6:443-446. https://doi. org/10.1038/74704. [PubMed]

54. Enrique AA, Gema PC, Jeronimo JC, Auxiliadora GE. Role of anti-EGFR target therapy in colorectal carcinoma. Front Biosci. 2012; 4:12-22. https://doi.org/10.2741/357. [PubMed]

55. Tejani MA, Cohen RB, Mehra R. The contribution of cetuximab in the treatment of recurrent and/or metastatic head and neck cancer. Biologics. 2010; 4:173-185. https:// doi.org/10.2147/BTT.S3050. [PubMed]

56. McCombs JR, Owen SC. Antibody Drug Conjugates: Design and Selection of Linker, Payload and Conjugation Chemistry. AAPS J. 2015; 17:339-351. https://doi. org/10.1208/s12248-014-9710-8. [PubMed]

57. Stefan N, Gébleux R, Waldmeier L, Hell T, Escher M, Wolter FI, Grawunder U, Beerli RR. Highly Potent, Anthracycline-based Antibody-Drug Conjugates Generated by Enzymatic, Site-specific Conjugation. Mol Cancer Ther. 2017; 16:879-892. https://doi.org/10.1158/1535-7163. MCT-16-0688. [PubMed]

58. Cole NB. Site-specific protein labeling with SNAP-Tags. Curr Protoc Protein Sci. 2013; 73:30.1.1-30.1.16. https:// doi.org/10.1002/0471140864.ps3001s73. [PubMed]

59. Los GV, Encell LP, Mcdougall MG, Hartzell DD, Karassina N, Zimprich C, Wood MG, Learish R, Ohana RF, Urh M, Simpson D, Mendez J, Zimmerman K, et al. Halo Tag: Protein labeling Technology for cell imaging and protein analysis. ACS Chem Biol. 2008; 3:373-382. https://doi. org/10.1021/cb800025k. [PubMed]

60. Zhao B, Wang L, Qiu H, Zhang M, Sun L, Peng P, Yu Q, Yuan X. Mechanisms of resistance to anti-EGFR therapy in colorectal cancer. Oncotarget. 2017; 8:3980-4000. https:// doi.org/10.18632/oncotarget.14012. [PubMed]

61. Juillerat A, Gronemeyer T, Keppler A, Gendreizig S, Pick H, Vogel H, Johnsson K. Directed Evolution of O6
-Alkylguanine-DNA Alkyltransferase for Efficient Labeling of Fusion Proteins with Small Molecules In Vivo. Chem Biol. 2003; 10:313-317. https://doi.org/10.1016/S10745521(03)00068-1. [PubMed]

62. Giusti RM, Cohen MH, Keegan P, Pazdur R. FDA Review of a Panitumumab (Vectibix) Clinical Trial for First-Line Treatment of Metastatic Colorectal Cancer. Oncologist. 2009; 14:284-290. https://doi.org/10.1634/theoncologist.2008-0254. [PubMed]

63. Mendez MJ, Green LL, Corvalan JR, Jia XC, MaynardCurrie CE, Yang XD, Gallo ML, Louie DM, Lee DV, Erickson KL, Luna J, Roy CM, Abderrahim H, et al. Functional transplant of megabase human immunoglobulin loci recapitulates human antibody response in mice. Nat Genet. 1997; 15:146-156. https://doi.org/10.1038/ng0297146. [PubMed]

64. Kaplon H, Reichert JM. Antibodies to watch in 2019. MAbs. 2019; 11:219-238. https://doi.org/10.1080/194208 62.2018.1556465. [PubMed]

65. Alsaab HO, Sau S, Alzhrani R, Tatiparti K, Bhise K, Kashaw SK, Iyer AK. PD-1 and PD-L1 checkpoint signaling inhibition for cancer immunotherapy: mechanism, combinations, and clinical outcome. Front Pharmacol. 2017; 8:561. https://doi.org/10.3389/fphar.2017.00561. [PubMed]

66. Brennan FR, Morton LD, Spindeldreher S, Kiessling A, Allenspach R, Hey A, Muller PY, Frings W, Sims J. Safety and immunotoxicity assessment of immunomodulatory monoclonal antibodies. MAbs. 2010; 2:233-55. https://doi. org/10.4161/mabs.2.3.11782. [PubMed]

67. Weiner LM, Dhodapkar MV, Ferrone S. Monoclonal antibodies for cancer immunotherapy. Lancet. 2009; 373:1033-40. https://doi.org/10.1016/S01406736(09)60251-8.

68. Su X, Lacouture ME, Jia Y, Wu S. Risk of high-grade skin rash in cancer patients treated with cetuximab-an antibody against epidermal growth factor receptor: systemic review and meta-analysis. Oncology. 2009; 77:124-133. https:// doi.org/10.1159/000229752. [PubMed]

69. Bria E, Cuppone F, Milella M, Verma S, Carlini P, Nisticò C, Vaccaro V, Rossi A, Tonini G, Cognetti F, Terzoli E. Trastuzumab cardiotoxicity: biological hypotheses and clinical open issues. Expert Opin Biol Ther. 2008; 8:19631971. https://doi.org/10.1517/14728220802517935. [PubMed]

70. Clark M, Cobbold S, Hale G, Waldmann H. Advantages of rat monoclonal antibodies. Immunol Today. 1983; 4:100-101. https://doi.org/10.1016/0167-5699(83)90013-0. [PubMed]

71. Schroff RW, Foon KA, Beatty SM, Oldham RK, Morgan AC. Human Anti-Murine Immunoglobulin Responses in Patients Receiving Monoclonal Antibody Therapy. Cancer Res. 1985; 45:879-885. [PubMed]

72. Bhatia S, Tykodi SS, Thompson JA. Treatment of metastatic melanoma: an overview. Oncology (Williston Park). 2009; 23:488-496. [PubMed] 
73. Safdari Y, Farajnia S, Asgharzadeh M, Khalili M. Antibody humanization methods - A review and update. Biotechnol Genet Eng Rev. 2013; 29:175-186. https://doi.org/10.1080 102648725.2013.801235. [PubMed]

74. Sanz L, Cuesta ÁM, Compte M, Álvarez-Vallina L. Antibody engineering: Facing new challenges in cancer therapy. Acta Pharmacol Sin. 2005; 26:641-648. https:// doi.org/10.1111/j.1745-7254.2005.00135.x. [PubMed]

75. Maloney DG. Preclinical and phase I and II trials of rituximab. Semin Oncol. 1999; 26:74-78. Available from http://europepmc.org/abstract/med/10561021.

76. Press OW. Radiolabeled Antibody Therapy of B-Cell Lymphomas. Semin Oncol. 1999; 26:58-65. [PubMed]

77. Sliwkowski MX, Lofgren JA, Lewis GD, Hotaling TE, Fendly BM, Fox JA. Nonclinical studies addressing the mechanism of action of trastuzumab (Herceptin). Semin Oncol. 1999; 26:60-70. [PubMed]

78. Padlan EA. Anatomy of the antibody molecule. Mol Immunol. 1994; 31:169-217. https://doi.org/10.1016/01615890(94)90001-9. [PubMed]

79. Carter P, Presta L, Gorman CM, Ridgway JB, Henner D, Wong WL, Rowland AM, Kotts C, Carver ME, Shepard HM. Humanization of an anti-p185HER2 antibody for human cancer therapy. Proc Natl Acad Sci U S A. 1992; 89:42854289. https://doi.org/10.1073/pnas.89.10.4285. [PubMed]

80. Fishwild DM, O'Donnell SL, Bengoechea T, Hudson DV, Harding F, Bernhard SL, Jones D, Kay RM, Higgins KM, Schramm SR, Lonberg N. High-avidity human IgG kappa monoclonal antibodies from a novel strain of minilocus transgenic mice. Nat Biotechnol. 1996; 14:845-851. https:// doi.org/10.1038/nbt0796-845. [PubMed]

81. Souriau C, Hudson PJ. Recombinant antibodies for cancer diagnosis and therapy. Expert Opin Biol Ther. 2003; 3:305-18. $\quad$ https://doi.org/10.1517/14712598.3.2.305. [PubMed]

82. Yang X, Jia X, Corvalan JRF, Wang P, Davis CG, Jakobovits A. Eradication of Established Tumors by a Fully Human Monoclonal Antibody to the Epidermal Growth Factor Receptor without Concomitant Chemotherapy. Cancer Res. 1999; 59:1236-1243.

83. Clark M. Antibody humanization: a case of the 'Emperor's new clothes'? Immunol Today. 2000; 21:397-402. https:// doi.org/10.1016/S0167-5699(00)01680-7. [PubMed]

84. Queen C, Schneider WP, Selick HE, Payne PW, Landolfi NF, Duncan JF, Avdalovic NM, Levitt M, Junghans RP, Waldmann TA. A humanized antibody that binds to the interleukin 2 receptor. Proc Natl Acad Sci U S A. 1989; 86:10029-10033. https://doi.org/10.1073/pnas.86.24.10029. [PubMed]

85. Co MS, Queen C. Humanized antibodies for therapy. Nature. 1991; 351:501-502. https://doi.org/10.1038/351501a0. [PubMed]

86. Hudson PJ. Recombinant antibody constructs in cancer therapy. Curr Opin Immunol. 1999; 11:548-557. https:// doi.org/10.1016/S0952-7915(99)00013-8. [PubMed]
87. Siemers NO, Kerr DE, Yarnold S, Stebbins MR, Vrudhula VM, Hellström I, Hellström KE, Senter PD. Construction, expression, and activities of L49-sFv-beta-lactamase, a single-chain antibody fusion protein for anticancer prodrug activation. Bioconjug Chem. 1997; 8:510-519. https://doi. org/10.1021/bc9700751. [PubMed]

88. Amoury M, Bauerschlag D, Zeppernick F, von Felbert V, Berges N, Di Fiore S, Mintert I, Bleilevens A, Maass N, Bräutigam K, Meinhold-Heerlein I, Stickeler E, Barth S, et al. Photoimmunotheranostic agents for triple-negative breast cancer diagnosis and therapy that can be activated on demand. Oncotarget. 2016; 7:54925-54936. https://doi. org/10.18632/oncotarget.10705. [PubMed]

89. von Felbert V, Bauerschlag D, Maass N, Bräutigam K, Meinhold-Heerlein I, Woitok M, Barth S, Hussain AF. A specific photoimmunotheranostics agent to detect and eliminate skin cancer cells expressing EGFR. J Cancer Res Clin Oncol. 2016; 142:1003-1011. https://doi.org/10.1007/ s00432-016-2122-7. [PubMed]

90. Kontermann RE. Recombinant bispecific antibodies for cancer therapy. Acta Pharmacol Sin. 2005; 26:1-9. https:// doi.org/10.1111/j.1745-7254.2005.00008.x. [PubMed]

91. Kampmeier F, Niesen J, Koers A, Ribbert M, Brecht A, Fischer R, Kiessling F, Barth S, Thepen T. Rapid optical imaging of EGF receptor expression with a single-chain antibody SNAP-tag fusion protein. Eur J Nucl Med Mol Imaging. 2010; 37:1926-1934. https://doi.org/10.1007/ s00259-010-1482-5. [PubMed]

92. Kline T, Steiner AR, Penta K, Sato AK, Hallam TJ, Yin G. Methods to Make Homogenous Antibody Drug Conjugates. Pharm Res. 2015; 32:3480-3493. https://doi.org/10.1007/ s11095-014-1596-8. [PubMed]

93. Jain N, Smith SW, Ghone S, Tomczuk B. Current ADC Linker Chemistry. Pharm Res. 2015; 32:3526-3540. https:// doi.org/10.1007/s11095-015-1657-7. [PubMed]

94. Beerli RR, Hell T, Merkel AS, Grawunder U. Sortase enzyme-mediated generation of site-specifically conjugated antibody drug conjugates with high In Vitro and In Vivo potency. PLoS One. 2015; 10:e0131177. https://doi. org/10.1371/journal.pone.0131177. [PubMed]

95. Blackstock D, Chen W. Halo-tag mediated self-labeling of fluorescent proteins to molecular beacons for nucleic acid detection. Chem Commun (Camb). 2014; 50:13735-13738. https://doi.org/10.1039/C4CC07118B. [PubMed]

96. Stagge F, Mitronova GY, Belov VN, Wurm CA, Jakobs S. Snap-, CLIP- and Halo-Tag Labelling of Budding Yeast Cells. PLoS One. 2013; 8:e78745. https://doi.org/10.1371/ journal.pone.0078745. [PubMed]

97. Gronemeyer T, Chidley C, Juillerat A, Heinis C, Johnsson K. Directed evolution of O6-alkylguanine-DNA alkyltransferase for applications in protein labeling. Protein Eng Des Sel. 2006; 19:309-316. https://doi.org/10.1093/ protein/gzl014. [PubMed]

98. Keppler A, Gendreizig S, Gronemeyer T, Pick H, Vogel H, Johnsson K. A general method for the covalent labeling of 
fusion proteins with small molecules in vivo. Nat Biotechnol. 2003; 21:86-89. https://doi.org/10.1038/nbt765. [PubMed]

99. Gautier A, Juillerat A, Heinis C, Corrêa IR, Kindermann M, Beaufils F, Johnsson K. An Engineered Protein Tag for Multiprotein Labeling in Living Cells. Chem Biol. 2008; 15:128-136. https://doi.org/10.1016/j. chembiol.2008.01.007. [PubMed]

100. Juillerat A, Heinis C, Sielaff I, Barnikow J, Jaccard H, Kunz B, Terskikh A, Johnsson K. Engineering substrate specificity of O6-alkylguanine-DNA alkyltransferase for specific protein labeling in living cells. Chembiochem. 2005; 6:1263-1269. https://doi.org/10.1002/cbic.200400431. [PubMed]

101. Bialon M, Grezella C, Friesen L, Sieben T, Pham AT, Fischer R, Barth S, Püttmann C, Stein C. A Monoclonal Antibody That Discriminates Between SNAP-Tagged and CLIP-Tagged Proteins. Monoclon Antib Immunodiagn Immunother. 2016; 35:141-147. https://doi.org/10.1089/ mab.2016.0002. [PubMed]

102. Hoehnel S, Lutolf MP. Capturing Cell-Cell Interactions via SNAP-tag and CLIP-tag Technology. Bioconjug Chem. 2015; 26:1678-1686. https://doi.org/10.1021/acs. bioconjchem.5b00268. [PubMed]

103. Kampmeier F, Ribbert M, Nachreiner T, Dembski S, Beaufils F, Brecht A, Barth S. Site-Specific, Covalent Labeling of Recombinant Antibody Fragments via Fusion to an Engineered Version of 6-O-Alkylguanine DNA Alkyltransferase. Bioconjug Chem. 2009; 20:1010-1015. https://doi.org/10.1021/bc9000257. [PubMed]

104. Kolberg K, Puettmann C, Pardo A, Fitting J, Barth S. SNAP-Tag Technology: A General Introduction. Curr Pharm Des. 2013; 19:5406-5413. https://doi.org/10.2174/ 13816128113199990514. [PubMed]

105. Gong H, Kovar JL, Baker B, Zhang A, Cheung L, Draney DR, Corrêa IR, Xu MQ, Olive DM. Near-infrared fluorescence imaging of mammalian cells and xenograft tumors with SNAP-tag. PLoS One. 2012; 7:e34003. https:// doi.org/10.1371/journal.pone.0034003. [PubMed]

106. Hussain AF, Kampmeier F, Von Felbert V, Merk HF, Tur MK, Barth S. SNAP-tag technology mediates site specific conjugation of antibody fragments with a photosensitizer and improves target specific phototoxicity in tumor cells. Bioconjug Chem. 2011; 22:2487-2495. https://doi. org/10.1021/bc200304k. [PubMed]

107. Woitok M, Klose D, Di Fiore S, Richter W, Stein C, Gresch G, Grieger E, Barth S, Fischer R, Kolberg K, Niesen J. Comparison of a mouse and a novel human scFv-SNAPauristatin $\mathrm{F}$ drug conjugate with potent activity against EGFR-overexpressing human solid tumor cells. Onco Targets Ther. 2017; 10:3313-3327. https://doi.org/10.2147/ OTT.S140492. [PubMed]

108. Kanugula S, Pegg AE. Alkylation damage repair protein O6-alkylguanine-DNA alkyltransferase from the hyperthermophiles Aquifex aeolicus and Archaeoglobus fulgidus. Biochem J. 2003; 375:449-455. https://doi. org/10.1042/bj20030809. [PubMed]
109. Alley SC, Okeley NM, Senter PD. Antibody-drug conjugates: targeted drug delivery for cancer. Curr Opin Chem Biol. 2010; 14:529-37. https://doi.org/10.1016/j. cbpa.2010.06.170. [PubMed]

110. Sievers EL, Senter PD. Antibody-Drug Conjugates in Cancer Therapy. Annu Rev Med. 2013; 64:15-29. https:// doi.org/10.1146/annurev-med-050311-201823. [PubMed]

111. Shefet-Carasso L, Benhar I. Antibody-targeted drugs and drug resistance-Challenges and solutions. Drug Resist Updat. 2015; 18:36-46. https://doi.org/10.1016/j. drup.2014.11.001. [PubMed]

112. Lewis Phillips GD, Li G, Dugger DL, Crocker LM, Parsons KL, Mai E, Blättler WA, Lambert JM, Chari RV, Lutz RJ, Wong WL, Jacobson FS, Koeppen H, et al. Targeting HER2-positive breast cancer with trastuzumab-DM1, an antibody-cytotoxic drug conjugate. Cancer Res. 2008; 68:9280-9290. https://doi.org/10.1158/0008-5472.CAN08-1776. [PubMed]

113. Pillow TH, Schutten M, Yu SF, Ohri R, Sadowsky J, Poon KA, Solis W, Zhong F, Del Rosario G, Go MAT, Lau J, Yee $\mathrm{S}, \mathrm{He} \mathrm{J}$, et al. Modulating therapeutic activity and toxicity of pyrrolobenzodiazepine antibody-drug conjugates with self-immolative disulfide linkers. Mol Cancer Ther. 2017; 16:871-878. https://doi.org/10.1158/1535-7163.MCT-160641. [PubMed]

114. Li F, Emmerton KK, Jonas M, Zhang X, Miyamoto JB, Setter JR, Nicholas ND, Okeley NM, Lyon RP, Benjamin DR, Law C. Intracellular Released Payload Influences Potency and Bystander-Killing Effects of Antibody-Drug Conjugates in Preclinical Models. Ther Targets. Chem Biol. 2016; 76:2710-2720. https://doi.org/10.1158/0008-5472. CAN-15-1795. [ [PubMed]

115. Biochempeg. Anti-Cancer ADC Drugs: 3 Design Elements, 7 Approved ADCs, Multiple Clinical Trials. 2020. Available from: https://www.biochempeg.com/article/74.html.

116. Lambert JM, Berkenblit A. Antibody-Drug Conjugates for Cancer Treatment. Annu Rev Med. Annual Reviews. 2018; 69:191-207. https://doi.org/10.1146/annurevmed-061516-121357. [PubMed]

117. Bai R, Pettit GR, Hamel E. Structure-activity studies with chiral isomers and with segments of the antimitotic marine peptide dolastatin 10. Biochem Pharmacol. 1990; 40:18591864. https://doi.org/10.1016/0006-2952(90)90367-T. [PubMed]

118. Kim EG, Kim KM. Strategies and advancement in antibody-drug conjugate optimization for targeted cancer therapeutics. Biomol Ther (Seoul). 2015; 23:493-509. https://doi.org/10.4062/biomolther.2015.116. [PubMed]

119. Bouchard H, Viskov C, Garcia-Echeverria C. Antibodydrug conjugates - A new wave of cancer drugs. Bioorg Med Chem Lett. 2014; 24:5357-5363. https://doi.org/10.1016/j. bmcl.2014.10.021. [PubMed]

120. Mittapalli RK, Stodtmann S, Friedel A, Menon RM, Bain E, Mensing S, Xiong H. An Integrated Population Pharmacokinetic Model Versus Individual Models of 
Depatuxizumab Mafodotin, an Anti-EGFR Antibody Drug Conjugate, in Patients With Solid Tumors Likely to Overexpress EGFR. J Clin Pharmacol. 2019; 59:12251235. https://doi.org/10.1002/jcph.1418. [ubMed]

121. Reilly EB, Phillips AC, Buchanan FG, Kingsbury G, Zhang Y, Meulbroek JA, Cole TB, Devries PJ, Falls HD, Beam C, Gu J, Digiammarino EL, Palma JP, et al. Characterization of ABT-806, a humanized tumor-specific anti-EGFR monoclonal antibody. Mol Cancer Ther. 2015; 14:11411151. https://doi.org/10.1158/1535-7163.MCT-14-0820. [PubMed]

122. van den Bent M, Gan HK, Lassman AB, Kumthekar P, Merrell R, Butowski N, Lwin Z, Mikkelsen T, Nabors LB, Papadopoulos KP, Penas-Prado M, Simes J, Wheeler $\mathrm{H}$, et al. Efficacy of depatuxizumab mafodotin (ABT-414) monotherapy in patients with EGFR-amplified, recurrent glioblastoma: results from a multi-center, international study. Cancer Chemother Pharmacol. 2017; 80:1209-1217. https://doi.org/10.1007/s00280-017-3451-1. [PubMed]

123. Senter PD. Potent antibody drug conjugates for cancer therapy. Curr Opin Chem Biol. 2009; 13:235-244. https:// doi.org/10.1016/j.cbpa.2009.03.023. [PubMed]

124. Li Z, Wang M, Yu D, Luo W, Fang J, Huang C, Yao X. Monomethyl auristatin E-conjugated anti-EGFR antibody inhibits the growth of human EGFR-positive non-small cell lung cancer. Cancer Chemother Pharmacol. 2019; 84:6172. https://doi.org/10.1007/s00280-019-03848-9. [PubMed]

125. Hinrichs MJM, Dixit R. Antibody Drug Conjugates: Nonclinical Safety Considerations. AAPS J. 2015; 17:1055-1064. https://doi.org/10.1208/s12248-015-97900. [PubMed]

126. Rosenthal M, Curry R, Reardon DA, Rasmussen E, Upreti VV, Damore MA, Henary HA, Hill JS, Cloughesy T. Safety, tolerability, and pharmacokinetics of anti-EGFRvIII antibody-drug conjugate AMG 595 in patients with recurrent malignant glioma expressing EGFRvIII. Cancer Chemother Pharmacol. 2019; 84:327-336. https://doi. org/10.1007/s00280-019-03879-2. [ubMed]

127. Mellinghoff IK, Wang MY, Vivanco I, Haas-Kogan DA, Zhu S, Dia EQ, Lu KV, Yoshimoto K, Huang JHY, Chute DJ, Riggs BL, Horvath S, Liau LM, et al. Molecular determinants of the response of glioblastomas to EGFR kinase inhibitors. N Engl J Med. 2005; 353:2012-2024. https://doi.org/10.1056/NEJMoa051918. [PubMed]

128. Hamblett KJ, Kozlosky CJ, Siu S, Chang WS, Liu H, Foltz IN, Trueblood ES, Meininger D, Arora T, Twomey B, Vonderfecht SL, Chen Q, Hill JS, Fanslow WC. AMG 595, an anti-EGFRvIII antibody-drug conjugate, induces potent antitumor activity against EGFRvIII-expressing glioblastoma. Mol Cancer Ther. 2015; 14:1614-1624. https://doi.org/10.1158/1535-7163.MCT-14-1078. [PubMed]

129. Jedema I, Barge RMY, van der Velden VHJ, Nijmeijer BA, van Dongen JJM, Willemze R, Falkenburg JHF. Internalization and cell cycle-dependent killing of leukemic cells by Gemtuzumab Ozogamicin: Rationale for efficacy in CD33-negative malignancies with endocytic capacity. Leukemia. 2004; 18:316-325. https://doi.org/10.1038/ sj.leu.2403205. [PubMed]

130. Cardillo TM, Govindan SV, Zalath MB, Rossi DL, Wang Y, Chang CH, Goldenberg DM. IMMU-140, a novel SN38 antibody-drug conjugate targeting HLA-DR, mediates dual cytotoxic effects in hematologic cancers and malignant melanoma. Mol Cancer Ther. 2018; 17:150-160. https://doi. org/10.1158/1535-7163.MCT-17-0354. [PubMed]

131. Adem YT, Schwarz KA, Duenas E, Patapoff TW, Galush WJ, Esue O. Auristatin antibody drug conjugate physical instability and the role of drug payload. Bioconjug Chem. 2014; 25:656-664. https://doi.org/10.1021/bc400439x. [PubMed]

132. Beckley NS, Lazzareschi KP, Chih HW, Sharma VK, Flores HL. Investigation into temperature-induced aggregation of an antibody drug conjugate. Bioconjug Chem. 2013; 24:1674-1683. https://doi.org/10.1021/bc400182x. [PubMed]

133. Moussa EM, Panchal JP, Moorthy BS, Blum JS, Joubert MK, Narhi LO, Topp EM. Immunogenicity of Therapeutic Protein Aggregates. J Pharm Sci. 2016; 105:417-430. https://doi.org/10.1016/j.xphs.2015.11.002. [PubMed]

134. McDonagh CF, Turcott E, Westendorf L, Webster JB, Alley SC, Kim K, Andreyka J, Stone I, Hamblett KJ, Francisco JA, Carter P. Engineered antibody-drug conjugates with defined sites and stoichiometries of drug attachment. Protein Eng Des Sel. 2006; 19:299-307. https://doi. org/10.1093/protein/gzl013. [PubMed]

135. Iwata TN, Ishii C, Ishida S, Ogitani Y, Wada T, Agatsuma TA. HER2-targeting antibody-drug conjugate, trastuzumab deruxtecan (DS-8201a), enhances antitumor immunity in a mouse model. Mol Cancer Ther. 2018; 17:14941503. https://doi.org/10.1158/1535-7163.MCT-17-0749. [PubMed]

136. Iwata TN, Sugihara K, Wada T, Agatsuma T. [Fam-] trastuzumab deruxtecan (DS-8201a)-induced antitumor immunity is facilitated by the anti-CTLA-4 antibody in a mouse model. PLoS One. 2019; 14:e0222280. https://doi. org/10.1371/journal.pone.0222280. [PubMed]

137. Wang W, Sun Q. Novel targeted drugs approved by the NMPA and FDA in 2019. Signal Transduct Target Ther. 2020; 5:65. https://doi.org/10.1038/s41392-020-0164-4. [PubMed]

138. Tamura K, Tsurutani J, Takahashi S, Iwata H, Krop IE, Redfern C, Sagara Y, Doi T, Park H, Murthy RK, Redman RA, Jikoh T, Lee C, et al. Trastuzumab deruxtecan (DS8201a) in patients with advanced HER2-positive breast cancer previously treated with trastuzumab emtansine: a doseexpansion, phase 1 study. Lancet Oncol. 2019; 20:816-26. https://doi.org/10.1016/S1470-2045(19)30097-X. [PubMed]

139. Shitara K, Iwata H, Takahashi S, Tamura K, Park H, Modi S, Tsurutani J, Kadowaki S, Yamaguchi K, Iwasa S, Saito K, Fujisaki Y, Sugihara M, et al. Trastuzumab deruxtecan 
(DS-8201a) in patients with advanced HER2-positive gastric cancer: a dose-expansion, phase 1 study. Lancet Oncol. 2019; 20:827-36. https://doi.org/10.1016/S14702045(19)30088-9. [PubMed]

140. Iwata H, Tamura K, Doi T, Tsurutani J, Modi S, Park H, Krop IE, Sagara Y, Redfern CH, Murthy RK, Redman RA, Shitara K, Fujisaki Y, et al. Trastuzumab deruxtecan (DS8201a) in subjects with HER2-expressing solid tumors: Long-term results of a large phase 1 study with multiple expansion cohorts. J Clin Oncol. 2018; 36:2501. https://doi. org/10.1200/JCO.2018.36.15 suppl.2501.

141. Nakada T, Sugihara K, Jikoh T, Abe Y, Agatsuma T. The Latest Research and Development into the Antibody-Drug Conjugate, [fam-] Trastuzumab Deruxtecan (DS-8201a), for HER2 Cancer Therapy. Chem Pharm Bull (Tokyo). 2019; 67:173-185. https://doi.org/10.1248/cpb.c18-00744. [PubMed]

142. Hamblett KJ, Senter PD, Chace DF, Sun MM, Lenox J, Cerveny CG, Kissler KM, Bernhardt SX, Kopcha AK, Zabinski RF, Meyer DL, Francisco JA. Effects of Drug Loading on the Antitumor Activity of a Monoclonal Antibody Drug Conjugate. Clin Cancer Res. 2004; 10:7063-7070. https://doi.org/10.1158/1078-0432.CCR04-0789. [PubMed]

143. Xie Y, Murray-Stewart T, Wang Y, Yu F, Li J, Marton LJ, Casero RA, Oupický D. Self-immolative nanoparticles for simultaneous delivery of microRNA and targeting of polyamine metabolism in combination cancer therapy. J Control Release. 2017; 246:110-119. https://doi. org/10.1016/j.jconrel.2016.12.017. [PubMed]

144. Shams M, Owczarczak B, Manderscheid-Kern P, Bellnier DA, Gollnick SO. Development of photodynamic therapy regimens that control primary tumor growth and inhibit secondary disease. Cancer Immunol Immunother. 2015; 64:287-297. https://doi.org/10.1007/s00262-014-1633-9. [PubMed]

145. Chiche J, Brahimi-Horn MC, Pouysségur J. Tumour hypoxia induces a metabolic shift causing acidosis: A common feature in cancer. J Cell Mol Med. 2010; 14:771-794. https:// doi.org/10.1111/j.1582-4934.2009.00994.x. [PubMed]

146. Lu J, Jiang F, Lu A, Zhang G. Linkers having a crucial role in antibody-drug conjugates. Int J Mol Sci. 2016; 17:561. https://doi.org/10.3390/ijms17040561. [PubMed]

147. Chari RVJ, Miller ML, Widdison WC. Antibody-drug conjugates: An emerging concept in cancer therapy. Angew Chem Int Ed Engl. 2014; 53:3796-3827. https://doi. org/10.1002/anie.201307628. [ubMed]

148. Jerjian TV, Glode AE, Thompson LA, O'Bryant CL. Antibody-Drug Conjugates: A Clinical Pharmacy Perspective on an Emerging Cancer Therapy. Pharmacotherapy. 2016; 36:99-116. https://doi.org/10.1002/phar.1687. [PubMed]

149. Woitok M, Klose D, Niesen J, Richter W, Abbas M, Stein C, Fendel R, Bialon M, Püttmann C, Fischer R, Barth S, Kolberg K. The efficient elimination of solid tumor cells by EGFR-specific and HER2-specific scFv-SNAP fusion proteins conjugated to benzylguanine-modified auristatin $\mathrm{F}$.
Cancer Lett. 2016; 381:323-330. https://doi.org/10.1016/j. canlet.2016.08.003. [PubMed]

150. Koga Y, Manabe S, Aihara Y, Sato R, Tsumura R, Iwafuji H, Furuya F, Fuchigami H, Fujiwara Y, Hisada Y, Yamamoto Y, Yasunaga M, Matsumura Y. Antitumor effect of antitissue factor antibody-MMAE conjugate in human pancreatic tumor xenografts. Int J Cancer. 2015; 137:1457-1466. https://doi.org/10.1002/ijc.29492. [PubMed]

151. Robertson CA, Evans DH, Abrahamse H. Photodynamic therapy (PDT): a short review on cellular mechanisms and cancer research applications for PDT. J Photochem Photobiol B. 2009; 96:1-8. https://doi.org/10.1016/j. jphotobiol.2009.04.001. [PubMed]

152. Henderson BW, Gollnick SO, Snyder JW, Busch TM, Kousis PC, Cheney RT, Morgan J. Choice of Oxygen-Conserving Treatment Regimen Determines the Inflammatory Response and Outcome of Photodynamic Therapy of Tumors. Cancer Res. 2004; 64:2120-2126. https://doi.org/10.1158/00085472.CAN-03-3513. [PubMed]

153. Jin J, Krishnamachary B, Mironchik Y, Kobayashi H, Bhujwalla ZM. Phototheranostics of CD44-positive cell populations in triple negative breast cancer. Sci Rep. 2016; 6:27871. https://doi.org/10.1038/srep27871. [PubMed]

154. Ito K, Mitsunaga M, Nishimura T, Kobayashi H, Tajiri H. Combination photoimmunotherapy with monoclonal antibodies recognizing different epitopes of human epidermal growth factor receptor 2: an assessment of phototherapeutic effect based on fluorescence molecular imaging. Oncotarget. 2016; 7:14143-14152. https://doi. org/10.18632/oncotarget.7490. [PubMed]

155. Burley TA, Mączyńska J, Shah A, Szopa W, Harrington KJ, Boult JKR, Mrozek-Wilczkiewicz A, Vinci M, Bamber JC, Kaspera W, Kramer-Marek G. Near-infrared photoimmunotherapy targeting EGFR - Shedding new light on glioblastoma treatment. Int J Cancer. 2018; 142:23632374. https://doi.org/10.1002/ijc.31246. [PubMed]

156. Mitsunaga M, Nakajima T, Sano K, Kramer-Marek G, Choyke PL, Kobayashi H. Immediate in vivo target-specific cancer cell death after near infrared photoimmunotherapy. BMC Cancer. 2012; 12:345. https://doi.org/10.1186/14712407-12-345. [PubMed]

157. Ito K, Mitsunaga M, Arihiro S, Saruta M, Matsuoka M, Kobayashi H, Tajiri H. Molecular targeted photoimmunotherapy for HER2-positive human gastric cancer in combination with chemotherapy results in improved treatment outcomes through different cytotoxic mechanisms. BMC Cancer. 2016; 16:37. https://doi. org/10.1186/s12885-016-2072-0. [PubMed]

158. Sato K, Choyke PL, Kobayashi H. Photoimmunotherapy of gastric cancer peritoneal carcinomatosis in a mouse model. PLoS One. 2014; 9:e113276. https://doi.org/10.1371/ journal.pone.0113276. [PubMed]

159. Berges N, Hehmann-Titt G, Hristodorov D, Melmer G, Thepen T, Barth S. Human Cytolytic Fusion Proteins: Modified Versions of Human Granzyme B and Angiogenin 
Have the Potential to Replace Bacterial Toxins in Targeted Therapies against CD64+ Diseases. Antibodies (Basel). 2014; 3:92-115. https://doi.org/10.3390/antib3010092.

160. Ito $K$, Mitsunaga $M$, Nishimura $T$, Saruta $M$, Iwamoto $T$, Kobayashi $H$, Tajiri H. Near-infrared photochemoimmunotherapy by photoactivatable bifunctional antibody-drug conjugates targeting Human Epidermal Growth Factor Receptor 2-positive cancer. Bioconjug Chem. 2017; 28:1458-1469. https://doi. org/10.1021/acs.bioconjchem.7b00144. [PubMed]

161. Penet MF, Chen Z, Kakkad S, Pomper MG, Bhujwalla ZM. Theranostic imaging of cancer. Eur J Radiol. 2012; 81:S124-6. https://doi.org/10.1016/S0720-048X(12)70051-7. [PubMed]

162. Harmatys KM, Overchuk M, Chen J, Ding L, Chen Y, Pomper MG, Zheng G. Tuning Pharmacokinetics to Improve Tumor Accumulation of a Prostate-Specific Membrane Antigen-Targeted Phototheranostic Agent. Bioconjug Chem. 2018; 29:3746-3756. https://doi. org/10.1021/acs.bioconjchem.8b00636. [PubMed]

163. Akbari B, Farajnia S, Zarghami N, Mahdieh N, Rahmati M, Khosroshahi SA, Barzegar A, Rahbarnia L. Construction, expression, and activity of a novel immunotoxin comprising a humanized antiepidermal growth factor receptor $\mathrm{scFv}$ and modified Pseudomonas aeruginosa exotoxin A. Anticancer Drugs. 2017; 28:263-270. https://doi.org/10.1097/ CAD.0000000000000452. [PubMed]

164. Pastan I, Kreitman RJ. Immunotoxins in cancer therapy. Curr Opin Investig Drugs. 2002; 3:1089-1091. https://doi. org/10.1007/978-1-4684-5574-8 7. [PubMed]

165. Kohno M, Horibe T, Haramoto M, Yano Y, Ohara K, Nakajima O, Matsuzaki K, Kawakami K. A novel hybrid peptide targeting EGFR-expressing cancers. Eur J Cancer. 2011; 47:773-783. https://doi.org/10.1016/j. ejca.2010.10.021. [PubMed]

166. Reiter Y, Pastan I. Recombinant Fv immunotoxins and Fv fragments as novel agents for cancer therapy and diagnosis. Trends Biotechnol. 1998; 16:513-520. https:// doi.org/10.1016/S0167-7799(98)01226-8. [PubMed]

167. Chandramohan V, Bigner DD. A novel recombinant immunotoxin-based therapy targeting wild-type and mutant EGFR improves survival in murine models of glioblastoma. OncoImmunology. 2013; 2:e26852. https://doi.org/10.4161/ onci.26852. [PubMed]

168. Seon BK. Specific Killing of Human T-Leukemia Cells by Immunotoxins Prepared with Ricin A Chain and Monoclonal Anti-Human T-Cell Leukemia Antibodies. Cancer Res. 1984; 44:259-264. [PubMed]

169. Kelley VE, Bacha P, Pankewycz O, Nichols JC, Murphy JR, Strom TB. Interleukin 2-diphtheria toxin fusion protein can abolish cell-mediated immunity in vivo. Proc Natl Acad Sci U S A. 1988; 85:3980-3984. https://doi.org/10.1073/ pnas.85.11.3980. [PubMed]
170. Bjorn MJ, Groetsema G, Scalapino L. Antibody-pseudomonas exotoxin a conjugates cytotoxic to human breast cancer cells in vitro. Cancer Res. 1986; 46:3262-3267. [PubMed]

171. Shim MS, Kwon YJ. Efficient and targeted delivery of siRNA in vivo. FEBS J. 2010; 277:4814-4827. https://doi. org/10.1111/j.1742-4658.2010.07904.x. [PubMed]

172. Akbari B, Farajnia S, Ahdi Khosroshahi S, Safari F, Yousefi M, Dariushnejad H, Rahbarnia L. Immunotoxins in cancer therapy: Review and update. Int Rev Immunol. 2017; 36:207-219. https://doi.org/10.1080/08830185.2017.1284211. [PubMed]

173. Meng J, Liu Y, Gao S, Lin S, Gu X, Pomper MG, Wang PC, Shan L. A bivalent recombinant immunotoxin with high potency against tumors with EGFR and EGFRvIII expression. Cancer Biol Ther. 2015; 16:1764-1774. https:// doi.org/10.1080/15384047.2015.1095403. [PubMed]

174. Schmidt M, Vakalopoulou E, Schneider DW, Wels W. Construction and functional characterization of $\mathrm{scFv}(14 \mathrm{E} 1)-$ ETA - a novel, highly potent antibody-toxin specific for the EGF receptor. Br J Cancer. 1997; 75:1575-1584. https://doi. org/10.1038/bjc.1997.270. [PubMed]

175. Zhou X, Qiu J, Wang Z, Huang N, Li X, Li Q, Zhang Y, Zhao C, Luo C, Zhang N, Teng X, Chen Z, Liu X, et al. In vitro and in vivo anti-tumor activities of anti-EGFR singlechain variable fragment fused with recombinant gelonin toxin. J Cancer Res Clin Oncol. 2012; 138:1081-1090. https://doi.org/10.1007/s00432-012-1181-7. [PubMed]

176. Liu TF, Cohen KA, Ramage JG, Willingham MC, Thorburn AM, Frankel AE. A diphtheria toxin-epidermal growth factor fusion protein is cytotoxic to human glioblastoma multiforme cells. Cancer Res. 2003; 63:1834-1837. [PubMed]

177. Thakur M, Mergel K, Weng A, von Mallinckrodt B, Gilabert-Oriol R, Dürkop H, Melzig MF, Fuchs H. Targeted tumor therapy by epidermal growth factor appended toxin and purified saponin: An evaluation of toxicity and therapeutic potential in syngeneic tumor bearing mice. Mol Oncol. 2013; 7:475-483. https://doi.org/10.1016/j. molonc.2012.12.004. [PubMed]

178. Dean GS, Pusztai L, Xu FJ, O’Briant K, DeSombre K, Conaway M, Boyer CM, Mendelsohn J, Bast RC. Cell surface density of p185(c-erbB-2) determines susceptibility to anti-p185(c-erbB-2)-Ricin A chain (RTA) immunotoxin therapy alone and in combination with anti-p170(EGFR)RTA in ovarian cancer cells. Clin Cancer Res. 1998; 4:2545-2550. [PubMed]

179. Chaudhary VK, FitzGerald DJ, Adhya S, Pastan I. Activity of a recombinant fusion protein between transforming growth factor type alpha and Pseudomonas toxin. Proc Natl Acad Sci U S A. 1987; 84:4538-4542. https://doi. org/10.1073/pnas.84.13.4538. [PubMed]

180. Brereton HM, Chamberlain D, Yang R, Tea M, McNeil S, Coster DJ, Williams KA. Single chain antibody fragments for ocular use produced at high levels in a commercial wheat variety. J Biotechnol. 2007; 129:539-546. https:// doi.org/10.1016/j.jbiotec.2007.01.008. [PubMed] 
181. Allured VS, Collier RJ, Carroll SF, McKay DB. Structure of exotoxin A of Pseudomonas aeruginosa at 3.0-Angstrom resolution. Proc Natl Acad Sci U S A. 1986; 83:1320-1324. https://doi.org/10.1073/pnas.83.5.1320. [ [

182. Bruell D, Bruns CJ, Yezhelyev M, Huhn M, Müller J, Ischenko I, Fischer R, Finnern R, Jauch KW, Barth S. Recombinant anti-EGFR immunotoxin 425(scFv)-ETA' demonstrates anti-tumor activity against disseminated human pancreatic cancer in nude mice. Int $\mathrm{J}$ Mol Med. 2005; 15:305-313. https://doi.org/10.3892/ijmm.15.2.305.

183. Kreitman RJ. Chimeric fusion proteins-Pseudomonas exotoxin-based. Curr Opin Investig Drugs. 2001; 2:128293. [PubMed]

184. Seetharam S, Chaudhary VK, Fitzgerald D, Pastan I. Increased Cytotoxic Activity of Pseudomonas Exotoxin and Two Chimeric Toxins Ending in KDEL*. J Biol Chem. 1991; 266:17376-17381. [PubMed]

185. Weldon JE, Xiang L, Chertov O, Margulies I, Kreitman RJ, Fitzgerald DJ, Pastan I. A protease-resistant immunotoxin against CD22 with greatly increased activity against CLL and diminished animal toxicity. Blood. 2009; 113:3792-3800. https://doi.org/10.1182/blood-2008-08-173195. [PubMed]

186. Ogata M, Chaudhary VK, Pastan I, FitzGerald DJ. Processing of Pseudomonas exotoxin by a cellular protease results in the generation of a 37,000-Da toxin fragment that is translocated to the cytosol. J Biol Chem. 1990; 265:20678-20685. [PubMed]

187. Jinno Y, Ogata M, Chaudhary VK, Willingham MC, Adhya S, FitzGerald D, Pastan I. Domain II mutants of pseudomonas exotoxin deficient in translocation. J Biol Chem. 1989; 264:15953-15959. [PubMed]

188. Niesen J, Stein C, Brehm H, Hehmann-Titt G, Fendel R, Melmer G, Fischer R, Barth S. Novel EGFR-specific immunotoxins based on panitumumab and cetuximab show in vitro and ex vivo activity against different tumor entities. J Cancer Res Clin Oncol. 2015; 141:2079-2095. https://doi. org/10.1007/s00432-015-1975-5. [PubMed]

189. Bruell D, Stöcker M, Huhn M, Redding N, Küpper M, Schumacher P, Paetz A, Bruns CJ, Haisma HJ, Fischer R, Finnern R, Barth S. The recombinant anti-EGF receptor immunotoxin 425(scFv)-ETA' suppresses growth of a highly metastatic pancreatic carcinoma cell line. Int J Oncol. 2003; 23:1179-1186. https://doi.org/10.3892/ ijo.23.4.1179. [PubMed]

190. Azemar M, Schmidt M, Arlt F, Kennel P, Brandt B, Papadimitriou A, Groner B, Wels W. Recombinant antibody toxins specific for ErbB2 and EGF receptor inhibit the in vitro growth of human head and neck cancer cells and cause rapid tumor regression in vivo. Int $\mathrm{J}$ Cancer. 2000; 86:269-275. https://doi.org/10.1002/(SICI)10970215(20000415)86:2<269::AID-IJC18>3.0.CO;2-8. [PubMed]

191. Bachran D, Schneider S, Bachran C, Urban R, Weng A, Melzig MF, Hoffmann C, Kaufmann AM, Fuchs H. Epidermal growth factor receptor expression affects the efficacy of the combined application of saponin and a targeted toxin on human cervical carcinoma cells. Int J Cancer. 2010; 127:1453-1461. https://doi.org/10.1002/ijc.25123. [PubMed]

192. Wels W, Beerli R, Hellmann P, Schmidt M, Marte BM, Kornilova ES, Hekele A, Mendelsohn J, Groner B, Hynes NE. EGF receptor and p185erbB-2-specific single-chain antibody toxins differ in their cell-killing activity on tumor cells expressing both receptor proteins. Int J Cancer. 1995; 60:137-144. $\quad$ https://doi.org/10.1002/ijc.2910600120. [PubMed]

193. Derynck R, Goeddel DV, Ullrich A, Gutterman JU, Williams RD, Bringman TS, Berger WH. Synthesis of Messenger RNAs for Transforming Growth Factors $\alpha$ and $\beta$ and the Epidermal Growth Factor Receptor by Human Tumors. Cancer Res. 1987; 47:707-712. [PubMed]

194. Rubin Grandis J, Melhem MF, Gooding WE, Day R, Holst VA, Wagener MM, Drenning SD, Tweardy DJ. Levels of TGF- $\alpha$ and EGFR protein in head and neck squamous cell carcinoma and patient survival. J Natl Cancer Inst. 1998; 90:824-832. https://doi.org/10.1093/jnci/90.11.824. [PubMed]

195. Scott AM, Wolchok JD, Old LJ. Antibody therapy of cancer. Nat Rev Cancer. 2012; 12:278-287. https://doi.org/10.1038/ nrc3236. [PubMed]

196. Weiner LM, O’Dwyer J, Kitson J, Comis RL, Frankel AE, Bauer RJ, Konrad MS, Groves ES, Phase I. Evaluation of an Anti-Breast Carcinoma Monoclonal Antibody 260F9Recombinant Ricin A Chain Immunoconjugate. Cancer Res. 1989; 49:4062-4067. [PubMed]

197. Baluna R, Vitetta ES. An in vivo model to study immunotoxin-induced vascular leak in human tissue. J Immunother. 1999; 22:41-7. https://doi. org/10.1097/00002371-199901000-00006. [PubMed]

198. Alderson RF, Kreitman RJ, Chen T, Yeung P, Herbst R, Fox J, Pastan I. CAT-8015: A second-generation Pseudomonas exotoxin a-based immunotherapy targeting CD22-expressing hematologic malignancies. Clin Cancer Res. 2009; 15:832839. https://doi.org/10.1158/1078-0432.CCR-08-1456. [PubMed]

199. Rand RW, Kreitman RJ, Patronas N, Glioma H, Varricchio F, Pastan I, Puri RK. Intratumoral Administration of Recombinant Circularly Permuted Interleukin-4Pseudomonas Exotoxin in Patients with High-Grade Glioma. Clin Cancer Res. 2000; 6:2157-65. [PubMed]

200. Kreitman RJ, Wilson WH, White JD, Stetler-Stevenson M, Jaffe ES, Giardina S, Waldmann TA, Pastan I. Phase I trial of Recombinant Immunotoxin Anti-Tac(Fv)- PE38 (LMB-2) in Patients With Hematologic Malignancies. J Clin Oncol. 2000; 18:1622-1636. https://doi.org/10.1200/ JCO.2000.18.8.1622. [PubMed]

201. Tsutsumi Y, Onda M, Nagata S, Lee B, Kreitman RJ, Pastan I. Site-specific chemical modification with polyethylene glycol of recombinant immunotoxin anti-Tac(Fv)PE38 (LMB-2) improves antitumor activity and reduces animal toxicity and immunogenicity. Proc Natl Acad Sci 
U S A. 2000; 97:8548-8553. https://doi.org/10.1073/ pnas.140210597. [ [PubMed]

202. Nagata S, Pastan I. Removal of B cell epitopes as a practical approach for reducing the immunogenicity of foreign protein-based therapeutics. Adv Drug Deliv Rev. 2009; 61:977-985. https://doi.org/10.1016/j.addr.2009.07.014. [PubMed]

203. Mazor R, King EM, Pastan I. Strategies to Reduce the Immunogenicity of Recombinant Immunotoxins. Am J Pathol. 2018; 188:1736-1743. https://doi.org/10.1016/j. ajpath.2018.04.016. [PubMed]

204. Mazor R, Onda M, Pastan I. Immunogenicity of therapeutic recombinant immunotoxins. Immunol Rev. 2016; 270:152164. https://doi.org/10.1111/imr.12390. [PubMed]

205. Mazor R, Onda M, Park D, Addissie S, Xiang L, Zhang J, Hassan R, Pastan I. Dual B- and T-cell de-immunization of recombinant immunotoxin targeting mesothelin with high cytotoxic activity. Oncotarget. 2016; 7:29916-29926. https://doi.org/10.18632/oncotarget.9171. [PubMed]

206. Hassan R, Williams-Gould J, Watson T, Pai-Scherf L, Pastan I. Pretreatment with Rituximab Does Not Inhibit the Human Immune Response against the Immunogenic Protein LMB-1. Clin Cancer Res. 2004; 10:16-18. https:// doi.org/10.1158/1078-0432.CCR-1160-3. [PubMed]

207. Hassan R, Miller AC, Sharon E, Thomas A, Reynolds JC, Ling A, Kreitman RJ, Miettinen MM, Steinberg SM, Fowler DH, Pastan I. Major Cancer Regressions in Mesothelioma After Treatment with an Anti-Mesothelin Immunotoxin and Immune Suppression. Sci Transl Med. 2013; 5:208ra147. https://doi.org/10.1126/scitranslmed.3006941. [PubMed]

208. Huhn M, Sasse S, Tur MK, Matthey B, Schinköthe T, Rybak SM, Barth S, Engert A. Human angiogenin fused to human CD30 ligand (Ang-CD30L) exhibits specific cytotoxicity against CD30-positive lymphoma. Cancer Res. 2001; 61:8737-42. https://doi.org/10.1016/S0959-8049(01)803518. [PubMed]

209. Weidle UH, Georges G, Brinkmann U. Fully human targeted cytotoxic fusion proteins: new anticancer agents on the horizon. Cancer Genomics Proteomics. 2012; 9:119-33. [PubMed]

210. Hetzel C, Bachran C, Fischer R, Fuchs H, Barth S, Stöcker M. Small cleavable adapters enhance the specific cytotoxicity of a humanized immunotoxin directed against CD64-positive cells. J Immunother. 2008; 31:370-376. https://doi.org/10.1097/CJ.0b013e31816a2d23. [PubMed]

211. Hristodorov D, Mladenov R, Pardo A, Pham AT, Huhn M, Fischer R, Thepen T, Barth S. Microtubule-associated protein tau facilitates the targeted killing of proliferating cancer cells in vitro and in a xenograft mouse tumour model in vivo. Br J Cancer. 2013; 109:1570-1578. https://doi. org/10.1038/bjc.2013.457. [PubMed]

212. Yoon JM, Han SH, Kown OB, Kim SH, Park MH, Kim BK. Cloning and cytotoxicity of fusion proteins of EGF and angiogenin. Life Sci. 1999; 64:1435-1445. https://doi. org/10.1016/S0024-3205(99)00077-6. [PubMed]

213. Amoury M, Kolberg K, Pham AT, Hristodorov D, Mladenov R, Di Fiore S, Helfrich W, Kiessling F, Fischer R, Pardo A, Thepen T, Hussain AF, Nachreiner T, Barth S. Granzyme B-based cytolytic fusion protein targeting EpCAM specifically kills triple negative breast cancer cells in vitro and inhibits tumor growth in a subcutaneous mouse tumor model. Cancer Lett. 2016; 372:201-209. https://doi. org/10.1016/j.canlet.2016.01.027. [PubMed]

214. Li P, Zheng G, Yang Y, Zhang C, Xiong P, Xu Y, Fang M, Tan Z, Zheng F, Gong F. Granzyme B is recovered by natural killer cells via clathrin-dependent endocytosis. Cell Mol Life Sci. 2010; 67:3197-3208. https://doi.org/10.1007/ s00018-010-0377-8. [PubMed]

215. Oberoi P, Jabulowsky RA, Bähr-Mahmud H, Wels WS. EGFR-Targeted Granzyme B Expressed in NK Cells Enhances Natural Cytotoxicity and Mediates Specific Killing of Tumor Cells. PLoS One. 2013; 8:e61267. https:// doi.org/10.1371/journal.pone.0061267. [PubMed]

216. Kurschus FC, Jenne DE. Delivery and therapeutic potential of human granzyme B. Immunol Rev. 2010; 235:159171. https://doi.org/10.1111/j.0105-2896.2010.00894.x. [PubMed]

217. Liu Y, Cheung LH, Hittelman WN, Rosenblum MG. Targeted delivery of human pro-apoptotic enzymes to tumor cells: In vitro studies describing a novel class of recombinant highly cytotoxic agents. Mol Cancer Ther. 2003; 2:1341-1350. [PubMed]

218. von Minckwitz G, Harder S, Hövelmann S, Jäger E, AlBatran SE, Loibl S, Atmaca A, Cimpoiasu C, Neumann A, Abera A, Knuth A, Kaufmann M, Jäger D, et al. Phase I clinical study of the recombinant antibody toxin $\mathrm{scFv}$ (FRP5)-ETA specific for the ErbB2/HER2 receptor in patients with advanced solid malignomas. Breast Cancer Res. 2005; 7:R617-R626. https://doi.org/10.1186/bcr1264. [PubMed]

219. Dälken B, Giesübel U, Knauer SK, Wels WS. Targeted induction of apoptosis by chimeric granzyme B fusion proteins carrying antibody and growth factor domains for cell recognition. Cell Death Differ. 2006; 13:576-585. https://doi.org/10.1038/sj.cdd.4401773. [PubMed]

220. Hirst CE, Buzza MS, Bird CH, Warren HS, Cameron PU, Zhang M, Ashton-Rickardt PG, Bird PI. The Intracellular Granzyme B Inhibitor, Proteinase Inhibitor 9, Is UpRegulated During Accessory Cell Maturation and Effector Cell Degranulation, and Its Overexpression Enhances CTL Potency. J Immunol. 2003; 170:805-815. https://doi. org/10.4049/jimmunol.170.2.805. [PubMed]

221. Kondo T, Oka T, Sato H, Shinnou Y, Washio K. Expression of proteinase inhibitor-9/serpinB9 in non-small cell lung carcinoma cells and tissues. Int J Oncol. 2009; 35:547-557.

222. Mathew M, Verma RS. Humanized immunotoxins: A new generation of immunotoxins for targeted cancer therapy. 
Cancer Sci. 2009; 100:1359-1365. https://doi.org/10.1111/ j.1349-7006.2009.01192.x. [PubMed]

223. Cremer C, Braun H, Mladenov R, Schenke L, Cong X, Jost E, Brümmendorf TH, Fischer R, Carloni P, Barth S, Nachreiner T. Novel angiogenin mutants with increased cytotoxicity enhance the depletion of pro-inflammatory macrophages and leukemia cells ex vivo. Cancer Immunol Immunother. 2015; 64:1575-1586. https://doi.org/10.1007/ s00262-015-1763-8. [PubMed]

224. Gorantla B, Asuthkar S, Rao JS, Patel J, Gondi CS. Suppression of the uPAR-uPA System Retards Angiogenesis, Invasion, and In Vivo Tumor Development in Pancreatic Cancer Cells. Mol Cancer Res. 2011; 9:377389. https://doi.org/10.1158/1541-7786.MCR-10-0452. [PubMed]

225. St Clair DK, Rybak SM, Riordan JF, Vallee BL. Angiogenin Abolishes Cell-Free Protein Synthesis by Specific Ribonucleolytic Inactivation of 40S Ribosomes. Biochemistry. 1988; 27:7263-7268. https://doi.org/10.1021/ bi00419a013. [PubMed]

226. Czech A, Wende S, Mörl M, Pan T, Ignatova Z. Reversible and Rapid Transfer-RNA Deactivation as a Mechanism of Translational Repression in Stress. PLoS Genet. 2013; 9:e1003767. https://doi.org/10.1371/journal.pgen.1003767. [PubMed]

227. Gresch G, Schenke L, Mladenov R, Zwirner S, Cremer C, Niesen J, Grieger E, Brümmendorf T, Jost E, Fischer R, Stockmeyer B, Barth S, Nachreiner T, Stein C. Elimination of different leukaemia subtypes using novel CD89-specific human cytolytic fusion proteins. Br J Haematol. 2018; 183:313-317. https://doi.org/10.1111/bjh.14971. [PubMed]

228. Mc Gee MM. Targeting the Mitotic Catastrophe Signaling Pathway in Cancer. Mediators Inflamm. 2015; 2015:146282. https://doi.org/10.1155/2015/146282. [PubMed]

229. Sacristan C, Kops GJ. Joined at the hip: kinetochores, microtubules, and spindle assembly checkpoint signaling. Trends Cell Biol. 2015; 25:21-28. https://doi.org/10.1016/j. tcb.2014.08.006. [PubMed]

230. Huang HC, Shi J, Orth JD, Mitchison TJ. Evidence that Mitotic Exit Is a Better Cancer Therapeutic Target Than Spindle Assembly. Cancer Cell. 2009; 16:347-358. https:// doi.org/10.1016/j.ccr.2009.08.020. [PubMed]

231. Jordan MA, Wilson L. Microtubules as a target for anticancer drugs. Nat Rev Cancer. 2004; 4:253-265. https:// doi.org/10.1038/nrc1317. [PubMed]

232. Kavallaris M. Microtubules and resistance to tubulinbinding agents. Nat Rev Cancer. 2010; 10:194-204. https:// doi.org/10.1038/nrc2803. [PubMed]

233. Brito DA, Rieder CL. Mitotic checkpoint slippage in humans occurs via cyclin B destruction in the presence of an active checkpoint. Curr Biol. 2006; 16:1194-1200. https://doi.org/10.1016/j.cub.2006.04.043. [PubMed]
234. Hristodorov D, Amoury M, Mladenov R, Niesen J, Arens K, Berges N, Hein L, Di Fiore S, Pham AT, Huhn M, Helfrich W, Fischer R, Thepen T, et al. EpCAM-Selective Elimination of Carcinoma Cells by a Novel MAP-Based Cytolytic Fusion Protein. Mol Cancer Ther. 2014; 13:21942202. https://doi.org/10.1158/1535-7163.MCT-13-0781. [PubMed]

235. Amoury M, Mladenov R, Nachreiner T, Pham AT, Hristodorov D, Di Fiore S, Helfrich W, Pardo A, Fey G, Schwenkert M, Thepen T, Kiessling F, Hussain AF, et al. A novel approach for targeted elimination of CSPG4-positive triple-negative breast cancer cells using a MAP tau-based fusion protein. Int J Cancer. 2016; 139:916-927. https://doi. org/10.1002/ijc.30119. [PubMed]

236. Bramblett GT, Goedert M, Jakes R, Merrick SE, Trojanowski JQ, Lee VMY. Abnormal tau phosphorylation at Ser396 in Alzheimer's disease recapitulates development and contributes to reduced microtubule binding. Neuron. 1993; 10:1089-1099. https://doi.org/10.1016/0896-6273(93)90057-X. [PubMed]

237. Hristodorov D, Nordlohne J, Mladenov R, Huhn M, Fischer R, Thepen T, Barth S. Human microtubuleassociated protein tau mediates targeted killing of CD30(+) lymphoma cells in vitro and inhibits tumour growth in vivo. Br J Haematol. 2014; 164:251-257. https://doi.org/10.1111/ bjh.12626. [PubMed]

238. Horn U, Strittmatter W, Krebber A, Knüpfer U, Kujau M, Wenderoth R, Müller K, Matzku S, Plückthun A, Riesenberg D. High volumetric yields of functional dimeric miniantibodies in Escherichia coli, using an optimized expression vector and high-cell-density fermentation under non-limited growth conditions. Appl Microbiol Biotechnol. 1996; 46:524-532. https://doi.org/10.1007/s002530050855. [PubMed]

239. Reichert J. Monoclonal Antibodies as Innovative Therapeutics. Curr Pharm Biotechnol. 2008; 9:423-430. https://doi.org/10.2174/138920108786786358. [PubMed]

240. Mazor R, Pastan I. Immunogenicity of Immunotoxins containing Pseudomonas Exotoxin A: Causes, Consequences and Mitigation. Front Immunol. 2020; 11:1261. https://doi. org/10.3389/fimmu.2020.01261. [PubMed]

241. Slastnikova TA, Ulasov AV, Rosenkranz AA, Sobolev AS. Targeted intracellular delivery of antibodies: The state of the art. Front Pharmacol. 2018; 9:1208. https://doi.org/10.3389/ fphar.2018.01208. [PubMed]

242. Pauthner M, Yeung J, Ullman C, Bakker J, Wurch T, Reichert JM, Lund-Johansen F, Bradbury AR, Carter PJ, Melis JP. Antibody Engineering \& Therapeutics, the annual meeting of The Antibody Society December 7-10, 2015, San Diego, CA, USA. MAbs. 2016; 8:617-52. https://doi. org/10.1080/19420862.2016.1153211. [PubMed] 